\title{
DENDRONEPHTHYA OF JAPAN, I. DENDRONEPHTHYA COLLECTED CHIEFLY ALONG THE COAST OF KII PENINSULA
}

\author{
$\operatorname{AUTHOR}(\mathrm{S}):$ \\ Utinomi, Huzio
}

CITATION:

Utinomi, Huzio. DENDRONEPHTHYA OF JAPAN, I. DENDRONEPHTHYA COLLECTED CHIEFLY ALONG THE COAST OF KII PENINSULA. PUBLICATIONS OF THE SETO MARINE BIOLOGICAL LABORATORY 1952, 2(2): 161-212

\section{ISSUE DATE:}

1952-10-05

URL:

http://hdl.handle.net/2433/174681

RIGHT: 


\title{
DENDRONEPHTHYA OF JAPAN, I. \\ DENDRONEPHTHYA COLLECTED CHIEFLY ALONG THE COAST \\ OF KII PENINSULA*
}

\author{
HUzio UTINOMI
}

Seto Marine Biological Laboratory, Sirahama

With Plates $I X-X I$ and 29-Text-figures

The spicular coral Dendronephthya (together with Stereonephthya), formerly known as Spongodes before the time of KüKENTHAL (1905), contains an enormous number of species, not fewer than 150 species, and is widely distributed in the warmer waters of the Indo-Pacific region, ranging from the Red Sea to Japan. An only exception is $D$. mexicana from the west coast of Mexico.

Up to this time the Japanese species of Dendronephthya have been studied by many authors, such as Stimpson, Verrill, Gray, STuder, Holm, Pütter, MAy, Kükenthal and Nutting. Of these authors, Verrill $(1864,1865)$ for the first time described 3 new species, one of which was from Ryukyu and two from Hongkong, based on STIMPson's collection. Next STUDER (1888) recorded 6 new species based on DöDerlein's collection, and Holm (1895) recorded 8 new species based on Suenson's collection. PütTer (1900) recorded 2 species as "von Ostasiatische Küste", together with 4 new species from China Sea, from Salmin's collection, and MAY (1900) also one new species from HILGENDORF's collection.

KüKENTHAL (1905), in his revision of the family Nephthyidae, enumerated and cescribed in detail all the known species in the world; in this he summed up about 20 species including 7 new species from Japanese waters. In the next year (1906) he described 9 known and 6 new species based on Doflein's and HABERER's vast collections. He (1911) later added one known species to the faunal list of Japan. Lastly Nurting (1923) recorded 2 known and 3 new species from the "Albatross" collection.

Summing up all existing records, there are no less than 33 species described from Japan, as belonging to this genus.

* Contributions from the Seto Marine Biological Laboratory, No. 182.

Publ. Seto Mar. Biol. Lab., II (2), 1952. (Article 10) 
To these many species of Dendronephthya I here add thirteen which are to be described as new species (marked by $* *$ in the appended table). And also of fifteen already described species, six are newly added to the fauna of Japan (marked by * in the table).1) The materials on which the descriptions of these species are based have been collected chiefly from shallow waters around the coast of Kii Peninsula, middle Japan. In addition to these materials from Japan, a description of a new species from Palao is included in this paper. Types of these new species, as well as other described species, are deposited in the zoological collections of the Seto Marine Biological Laboratory.

Such an enormous addition is not so surprising, since the previous collections of Japanese Alcyonarians which have been made by foreigners and by expeditions are mostly confined to rather deep-water forms, mostly in depths more than 20 fathoms, and therefore lacking in reef forms. As far as I have experienced, Dendronephihya (Stereonephthya also) seems to be very luxuriant along the Pacific coast of southern Japan, probably more than in tropical seas, and may be easily observed alive on the shore. All the material to be described here are those obtained by shore collecting or by dredging in shallower waters than 30 meters in depth, unless otherwise particularly mentioned.

The difficulty of taxonomy of Dendronephthya lies in the enormous number of species of the group which differ from one another only in very minute characters. KüKENTHAL (1905), in his excellent work of revision, arranged it in three main divisions: (1) Glomeratae, (2) Divaricatae and (3) Umbellatae, based on the growth form of the colony. He then splitted these groups into many minor sections with different modes of branching. SHerrifFs (1922), based on the examination of this group of the "Siboga" collection, proposed the useful system of "anthocodial grade and formula" according to the differences of the anthocodial armature which example was followed by THoмson and DEAN (1931) and Roxas (1933).

Both systems are very useful in the taxonomy of this group, but not yet sufficient to raise these groups to the status of distinct subgenera or even genera. Therefore, the present system of classification is still of a relatively

1) After this report was written, the following 5 species which were collected by Mr. T. YAMAMOTO at Kusimoto have been newiy added to my collection :

D. suensoni (HOI.M)-Divaricatae.

D. gracillima KÜKENTHAL-Divaricatae.

D. sp. nov. A-Divaricatae.

$D$. sp. nov. B-Divaricatae.

D. ct. flabellifera (STUDER;-Umbellatae.

The description of these species will be given in another paper. 
trivial sort. But in doing so and thereby adopting the combined classification of KÜKENTHAi's and SHERRIFFs' systems, I must confess that KükENTHAL's system is more useful to arrange a number of species into major groups by mere superficial examination than SherRiffs'system. However, Kükenthal's system may afford further confusion in the systematic arrangement from the phylogenetic point of view, if laying much stress on the evolution of anthocodial armature alone, as clone by ShERRIFFs. The problem as to the evolution of species is thus still unsettled.

The classification followed herein is that of KüKENTHAL (1905), with some modification of Sterrifrs' anthocodial formula, in which I am using, in addition, the pairs of intermediate spicules abbreviated as " $M$ "; in this case if intermediate spicules are unpaired, it is given as " $\frac{1}{2} \mathrm{M}$ ". All other grades are followed SHERRIFFs. To simplify the descriptions of species I use herein the abbreviated term "S.B." for the supporting bundle or "Stützbündel" in texts as in the anthocodial formula.

In pursuing this study I am greatly indebted to my revered teacher, Emer. Prof. Taku KomaI for his kind suggestion and constant encouragement. Thanks are also due to Messrs. T. Yamanouchi, T. Yamamoto, M. Ozaki, S. SAKAgUCHI, S. URA and $Y$. SAIKA for assistance in collecting the material. The work was aided by a grant from the Scientific Research Expenditure of the Ministry of Education.

TABLE OF THE SPECIES EXAMINED

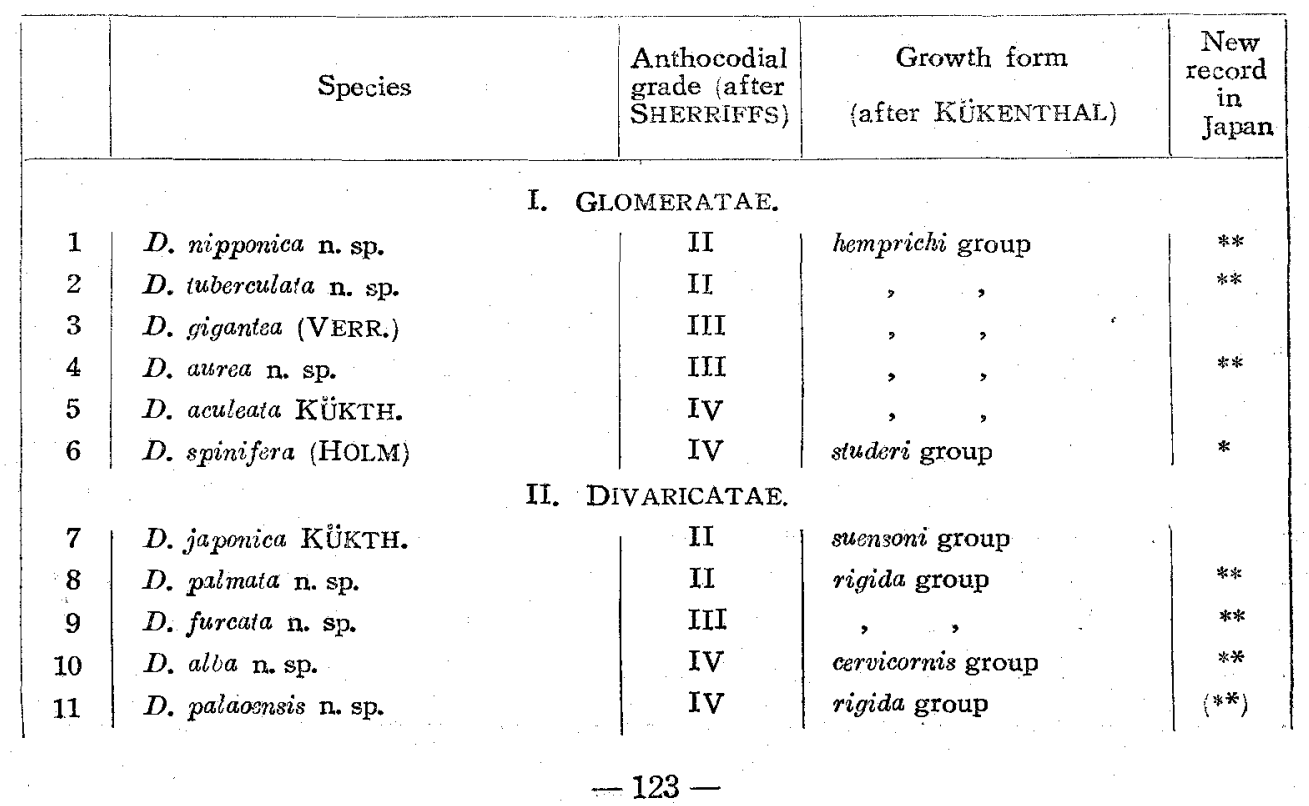




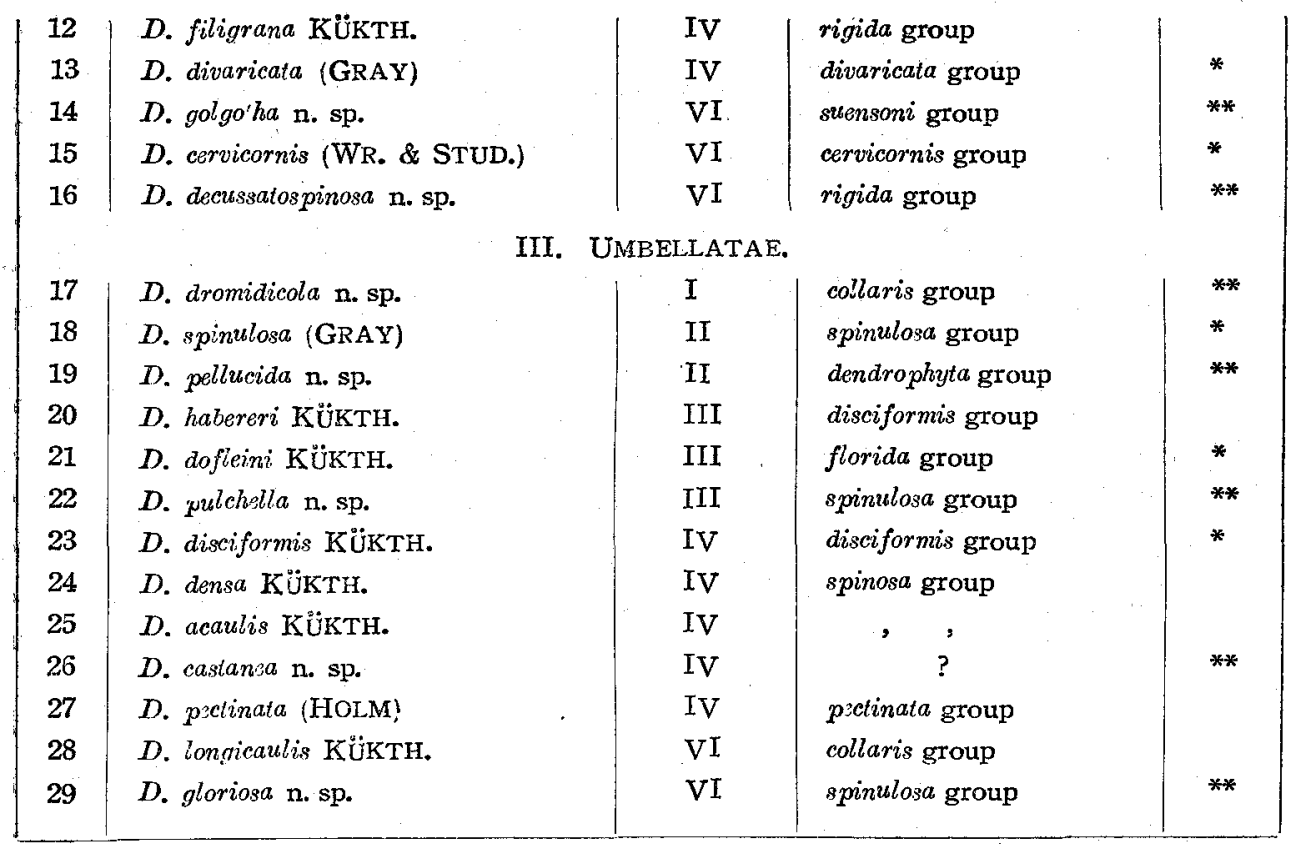

\section{Glomerat AE}

\section{Dendronephthya nipponica n. sp.}

(Fig. 1; Plate IX, Figs. 1, 2)

D. spec. aff. hemprichi, KƯKENTHAL (1906, p. 38).

Glomerate. Colony rigid, low and bushy, with encrusting flat base. From a short, robust, cylindrical stalk arise erect one or more main branches, that in turn give off some secondary branches roundly ended. Base of lowest branches foliaceous to form a complete collar around stem. Total height very variable ranging from $3.5 \mathrm{~cm}$ to $17 \mathrm{~cm}$, of which about one-fourth or one-fffth belongs to sterile stalk.

Polyps in compact groups of 5 to 12 on main branches and twigs. Polyp head rounded flat cuplike, about $0.35-0.45 \mathrm{~mm}$ high and $0.7-0.8 \mathrm{~mm}$ wide, standing at an obtuse angle with very short and plump stalk, usually shorter than $0.5 \mathrm{~mm}$; ventral side of polyp stalk below head usually with very few rodlike small spicules or nude. Anthocodial armature in eight double rows of 5-7 converging pairs; uppermost one or two of points a little longer than the rest, up to $0.3 \mathrm{~mm}$ in length, usually incurved but not far extended upright. No crown spicules present. S. B. strongly developed, of which 1 or 2 large spicules 
up to $2.6 \mathrm{~mm}$ long and $0.24 \mathrm{~mm}$ wide, densely spinose throughout, except at extremities only and project for about $0.5 \mathrm{~mm}$ long beyond polyp head. Tentacle spicules opaque, red, oval to elongate, up to $0.035 \mathrm{~mm}$ long and sparsely set in two rows. Anthocodial formula:

$$
\mathrm{II}=(5-7) \mathrm{p}+0 \mathrm{Cr}+\text { strong S.B. }+(0-3) \mathrm{M}
$$
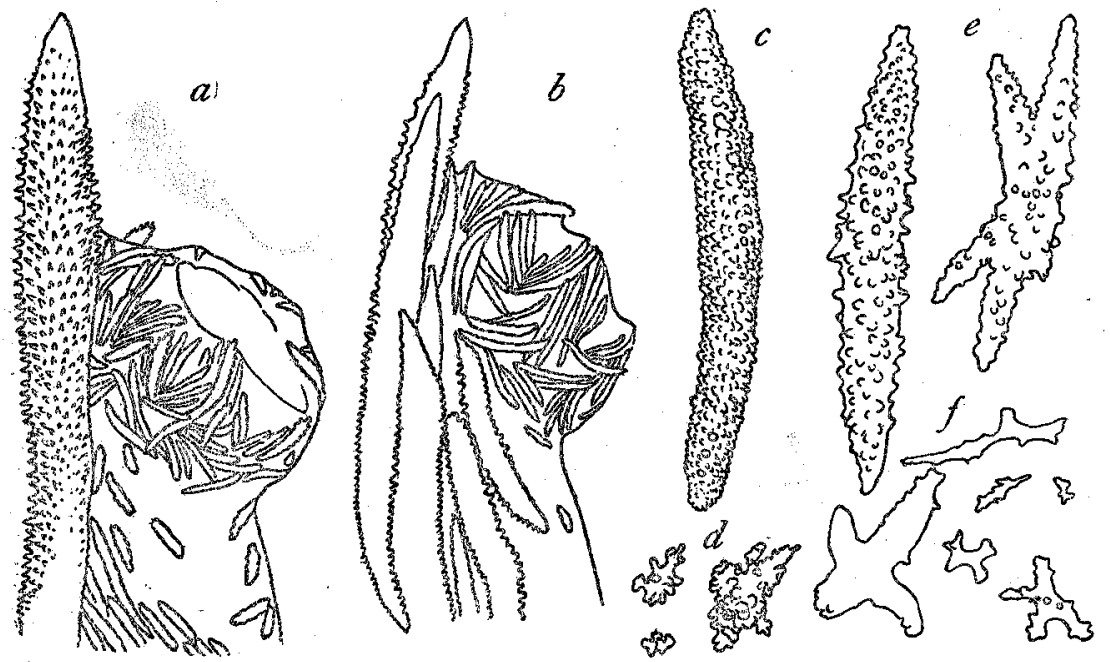

Fig. 1. Dendronephthya nipponica n. sp. $a, b$, Polyp; $c$, spindle from upper cortex; $d$, stellate spicules from lower cortex; $e$, warty spindle and quadriradiate from canal-walls; $f$, flat spicules from canal-walls. (All $\times 35$ )

On cortex of branches and twigs are white spindles covered with closeset rounded warts, up to $3 \mathrm{~mm}$ long, lying transversely. On lower cortex are mostly smaller stellate or irregular-shaped forms of various dimensions, together with short, curved, plump spindles with tuberculate warts, relatively fewer in number. Canal-walls sparsely filled with coloriess, robust spindles, triradiates or quadriradiates with rounded warts up to $1.5 \times 0.18 \mathrm{~mm}$. In addition there are tiny flat rods, triradiates and quadriradiates with a few low warts.

Coloring. Polyp spicules blood-red or purple, but polyps themselves yellowish white. Branch and stalk greyish white, often tinged with red at base.

Locality. Very common around Kii coast, from shore to $100 \mathrm{~m}$ depth. Probably widely distributed along the Pacific coast of Japan as far north as Sagami Bay.

Remarks. KüKENTHAL (1906) suggests a close affinity of this form from Sagami Bay with $D$. hemprichi (KLunzINGER) which is known to occur in Red Sea and East African coast. He gave no account, however, for the specific 
differences between the Japanese and Red Sea forms. I have had no opportunity to examine the Red Sea specimens of $D$. hemprichi, but from the detailed descriptions of the latter in comparison with allied forms given by THOMSON and MCQUEEN (1908), there seems to be no doubt about the distinctness of the Japanese species from that of Red Sea. Distributional gap may warrant this view, no specimen referred to $D$. hemprichi having ever been recorded from the Indian, Malayan and Philippine regions.

\section{Dendronephthya tuberculata $\mathrm{n}$. sp.}

(Fig. 2; Plate IX, Fig. 5)

Glomerate. Colony very compact and stout, having a superficial resemblance to $D$. giganiea. From a short, broadly expanded base arises a columnar, stout, erect stem which gives off about eight short main branches wholly covered with a number of short polyp-bearing twigs of approximately equal length, less than $5 \mathrm{~mm}$. Lowest branches slightly foliaceous, completely encircling stem at base of polyparium. In one of four specimens examined, polyparium is $8 \mathrm{~cm}$ by $7 \mathrm{~cm}$ and sterile stalk $2-3 \mathrm{~cm}$ in height; in the other one, polyparium $4 \mathrm{~cm}$ high and sterile stalk $1-2 \mathrm{~cm}$ high. In young form attached to base of a larger colony, its total height is about $3.5 \mathrm{~cm}$, and polyparium and stalk are almost similar in length.

Polyps in compact groups of 10 to 20 at ends of twigs. Polyp head about $0.6 \mathrm{~mm}$ long and $0.7 \mathrm{~mm}$ wide, standing at an obtuse angle with short, stout polyp stalk, at most $0.6-0.8 \mathrm{~mm}$ long and $0.58 \mathrm{~mm}$ wide at base. S. B. of the entheathing type, consists of about 6 large plump spindles up to $2 \mathrm{~mm}$ long and numerous smaller accessory ones, about $0.5-1.2 \mathrm{~mm}$ long; they are all very tuberculate throughout and bluntly ended, uppermost larger ones slightly project beyond polyp head. Polyp armature composed of eight double rows of compactly disposed, orange-colored, tuberculate spindles similar to S.B. spicules, giving the polyp a pebby ornamentation. Uppermost points often broadly tipped in a club-like shape. Point spicules on lateral sides 6-8 in a row, approximately similar in size, usually $0.3 \mathrm{~mm}$ long and $0.035 \mathrm{~mm}$ wide; they become smaller and fewer towards ventral side, where they are often 5-6 in a row. 2-4 small, less-tuberculate intermediate spicules occur at the lowest angle between points. Tentacles very long, about $0.52 \mathrm{~mm}$ long, with many long slender pinnules and with a few orange-colored, minute rodlike spicules, about $0.05 \mathrm{~mm}$ long, irregularly disposed but converging downwards. Ventral side of polyp stalk provided with a few orangish, somewhat flat, less-tuberculate 


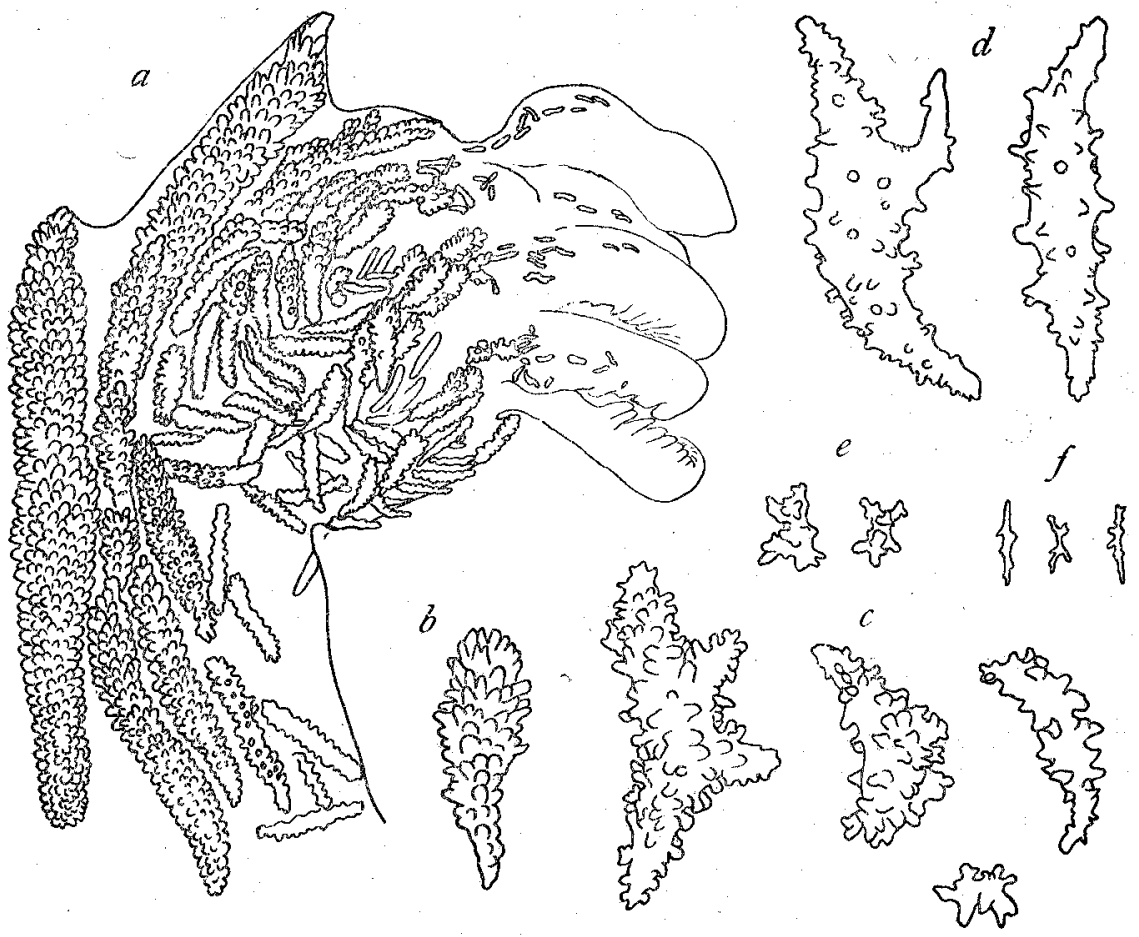

Fig. 2. Dendron hhthya tuberculata n. sp. $a$, Polyp; $b$, club-shaped uppermost point spicule; $c$, spicules from lower cortex; $d$, large spicules from canal-walls; $a$, small stars from canalwalls ; $f$, minute flat rods "from canal-walls. $(6 \times 80$, all the others $\times 55)$

spindles between highly tuberculate, yellowish accessory spicules of S.B. Anthocodial formula :

$$
I I=(6-8) p+0 \text { Cr+strong S.B. }+(1-2) \mathrm{M}
$$

On cortex of stem and branches are transversely arranged, white or yellowish, spindles with close-set, prominent rounded warts, up to $3 \mathrm{~mm}$ long. On lower cortex, in addition to superficially disposed larger spindles similar to those of upper cortex, there occur shorter, curved spindles which pass to pseudo-clubs, almost globular stellate forms, mostly $0.35-0.53 \mathrm{~mm}$ long and rarely much smaller stars, about $0.17-0.25 \mathrm{~mm}$ long. Canal-walls thickly filled with three kinds of colorless spicules as follows:

(a) Large spindles or triradiates with few conical or truncated warts; $0.4 \times 0.07 \mathrm{~mm}, 0.53 \times 0.05 \mathrm{~mm}, 0.85 \times 0.11 \mathrm{~mm}$.

(b) Small stars, similar to those of basal cortex; mostly $0.17-0.25 \mathrm{~mm}$ long.

(c) Minute, slightly toothed, elongate flat rod; $\operatorname{mostly} 0.05-0.12 \mathrm{~mm}$ long. 
Coloring. On the whole rusty or orange in color. Examination with a lens shows, however, that polyps are reddish orange, S.B. orangish yellow, and branch and stalk greyish yellow mottled with white, depending on the coloration of spicules.

Localities. Kii-ôsima. 1940. S. SAKaguchI leg.; (paratype) Minabe. 1952. M. OzAKI leg.

Remarks. This form is closely allied to $D$. gigantea and $D$. aurea in its color scheme and ramification, but differs distinctly in the strongly tuberculate spicules of polyps.

\section{Dendronephthya gigantea (VERRILL)}

(Fig. 3; Plate IX, Figs. 3, 4)

Spongodes gigantea, VERRILL $\{1864$, p. 40).

Spongodes glomerata, STUDER (1888, p. 70 \%

Dendronephthya gigantea, KüKENTHAL $(1905$, p. 549; 1906, p. 39), THOMSON \& MACKINNON (1910, p. 184), THOMSON \& DEAN (1931, p. 105), ROXAS (1933, p. 435).

Glomerate colony with flat base, broadly encrusting on rock or stones. In largest one examined, polyparium, consisting of several erect, stout columnar main stems and branches, is $19 \mathrm{~cm}$ in height and $3-4 \mathrm{~cm}$ in diameter of largest stem at base and sterile stalk $5-6 \mathrm{~cm}$ in height. - Base of lowest branches distinctly foliaceous and forms a collar almost completely encircling the stem.

Polyps densely grouped in large rounded masses of 5-15 at tips of 2-3 $\mathrm{mm}$ long twigs. In young colonies polyp-bearing twigs compactly crowded all over the surface, so that the underlying main stem and branches may be completely hidden.

Polyp head more or less rounded, rather large, about $0.6 \mathrm{~mm}$ long and $0.9 \mathrm{~mm}$ wide, making a very obtuse angle with short and plump polyp stalk less than $1 \mathrm{~mm}$ long. Anthocodial armature in eight double rows, about 5 to 6 in a row. Uppermost points usually twice as long as the rest and wholly covered by epidermis, even toward their tips; uppermost one on each lateral side often markedly predominates up to $0.7 \times 0.07 \mathrm{~mm}$, strongly projecting far out of head, and if so, invariably tipped with white. S.B. strongly developed, composed of 3-7 spicules wholly covered with prominent warts, of which one or two are as long as $4 \mathrm{~mm}$ and project beyond polyp head for about $1-1.5 \mathrm{~mm}$ long. Tentacle spicules apparently absent, but when present, may be of small oval rod of red color, sparsely disposed basally. Ventral side of polyp stalk just below head free from spicules. Anthocodial formula: 


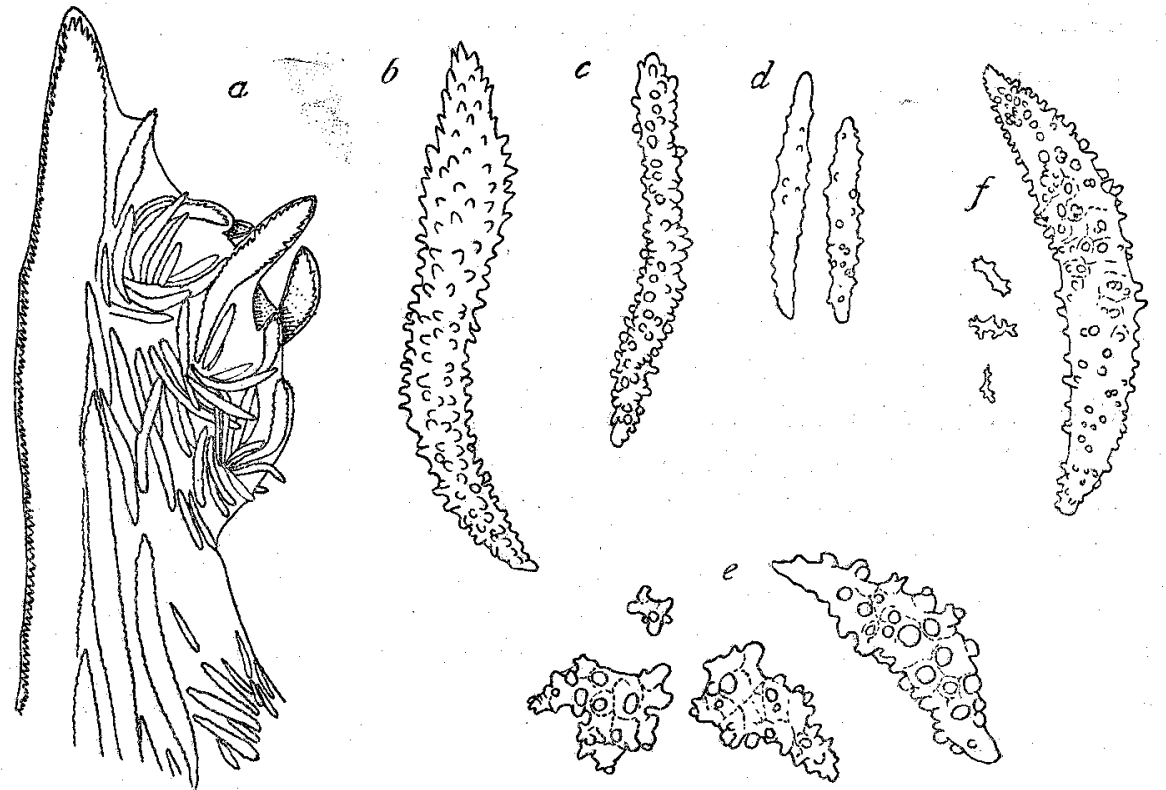

Fig. 3. Dendronephthya gigantea (VERR.). $a$, Polyp; $b$, strongly projecting uppermost point in laterals; $c$, slightly projecting uppermost point; $d$, lower point spicules; $e$, spicules from lower cortex; $f$, spindle and antlers from canal-walls. $(a, f \times 35, e \times 55, b-d \times 80)$

$$
I I I=1 P+(4-5) p+0 \text { Cr + very strong S.B.+ }(0 \text { or } 1) \mathrm{M}
$$

On cortex of upper stem and branches are large spindles about $4 \mathrm{~mm}$ long, covered with large, simply rounded and rugged or compound warts, mostly lying transversely. Lower cortex and canal-walls contain smaller and stouter, heavily warted spindles, triradiates and multiradiates, about $0.08-0.8$ $\mathrm{mm}$ long and $0.017 \mathrm{~mm}$ wide. Besides much smaller, quite irregular forms somewhat like antler type may be seen.

Coloring. Very variable, but generally polyps are red or reddish orange. S.B. spicules and projecting tip of uppermost points white, often yellow to orange. Branch and stem white or whitish yellow. Stalk yellowish, orange or reddish.

Locality. Very common in the littoral of $\mathrm{Kii}$ coast, probably all around the southern coast of Japan.

Previously recorded from Japan, Hongkong, Philippines, Malay Archipelago and Amirante (Indian Ocean), from 1 to $200 \mathrm{~m}$ in depth.

Remarks. Kükenthal (1905), on examining the original specimens of Holm, expressed the opinion that Spongodes aspera Holm (1895) from Hirudo (=Hirado) Strait is merely a synonym of $D$. gigantea. However I suspect its identity because of the remarkable differences in coloration and spiculation, 
especially of the polyps. It is in all probability a young form of Dendronephthya suensoni (HOLM).

\section{Dendronephthya aurea n. sp.}

(Fig. 4 ; Plate IX, Fig. 7)

The mode of branching and habit correspond exactly with those of the preceding $D$. nipponica and $D$. gigantea, being markedly of the glomerate type and having foliaceous lowest branches at the base of polyparium. Therefore the colony also must be included in KüKenthaL's hemprichi-group. But the coloration is quite different.

Largest one among a number of examined colonies has a total height of $17 \mathrm{~cm}$ of which about $3 \mathrm{~cm}$ belongs to sterile stalk. Polyps in compact groups of 5-10. Polyp head flat cuplike, about $0.44-0.55 \mathrm{~mm}$ long and $0.7-0.97$ $\mathrm{mm}$ wide, standing at a very obtuse angle with short stalk up to $1 \mathrm{~mm}$ long. Anthocodial armature in eight double rows, about $5-6$ in a row. Point spicules of subequal length, about $0.25-0.35 \mathrm{~mm}$ long, mostly $0.3 \mathrm{~mm}$ long and 0.035 $\mathrm{mm}$ wide; the outermost one or a pair up to $0.35-0.5 \mathrm{~mm}$ long and $0.05 \mathrm{~mm}$
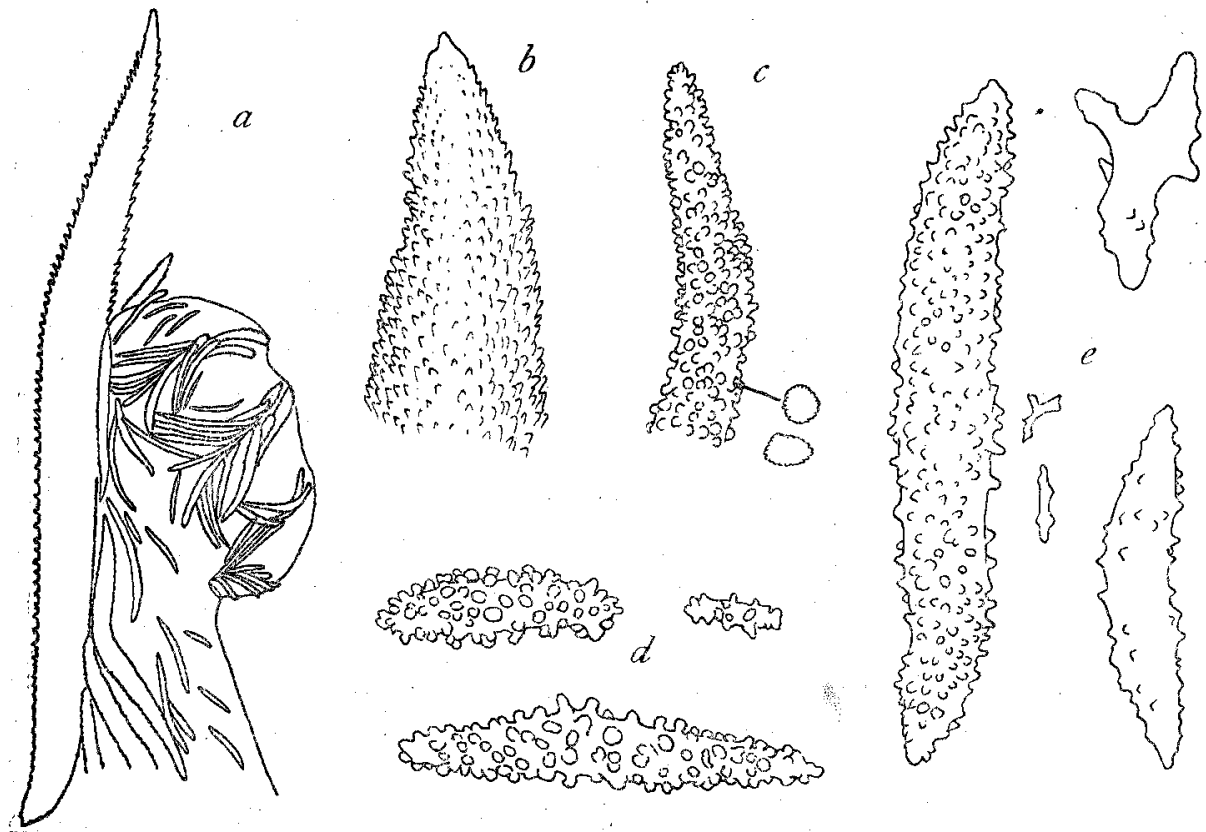

Fig. 4. Dendronephthya arrea n. sp. $a$, Polyp; $b$, tip of S.B. spicule; $c$, part of spindle from upper cortex; $d$, spindles from lower cortex; $e$, spicules from canal-walls. $(a \times 35, b-a \times 55)$ 
wide, broadly tipped, sometimes markedly extend beyond polyp head. Tentacles white, small and apparently devoid of spicules. S.B. strongly developed, composed of 1-3 strong warty spindles, about $2.5-3.5 \mathrm{~mm}$ long and $0.26-0.3 \mathrm{~mm}$ wide; projecting tip for about $0.5-1.0 \mathrm{~mm}$ long strongly spinose towards ends. Polyp stalk very plump and on ventral side with a few small spicules only basally. These spicules are all apricot-orange in color. Anthocodial formula: III $=1 \mathrm{P}+(4-5) \mathrm{p}+0 \mathrm{Cr}+$ very strong S.B. $+(0-1) \mathrm{M}$

On upper cortex are all white spindles up to $3 \mathrm{~mm}$ long and $0.3 \mathrm{~mm}$ wide, with close-set rounded warts jagged terminally. On lower cortex are greyish yellow warty spindles up to $1.5 \mathrm{~mm}$ long and $0.17 \mathrm{~mm}$ wide, and also much smaller ones, mostly $0.3-0.4 \mathrm{~mm}$ long, no triradiates being found. Canalwalls thickly flled with colorless, plump spindles with few warts up to $1.8 \times$ $0.23 \mathrm{~mm}$, triradiates and smaller rods, about $0.17 \mathrm{~mm}$ long.

Coloring. Stalk greyish yellow, branch cortex white, polyp and S.B. spicules gold-yellow to orange, while polyps themselves yellowish white.

Locality. Very common around Kii coast, just below low-tide level.

\section{Dendronephthya acul eata KÜKENTHAL}

(Fig. 5 ; Plate IX, Fig. 6)

Dendronephthya aculeata, KửKENTHAL. (1905, p. 559).

D. aculatea (sic), ROXAS (1933, p. 438).

A very compact and rigid colony with a very short stalk completely hidden. Polyparium of a roughly long oval outline, about $8 \mathrm{~cm}$ high and $3.5-$ $4.5 \mathrm{~cm}$ broad, with about eight main branches completely covered with roundly headed groups of twigs. Lowest branches foliaceous. All polyps superficial, being located at ends of closely massed twigs, so that any bare cortex of stem and branches is entirely invisible from outsides.

Polyps in groups of 6-15 at ends of dichotomously branched twigs. Polyp head small, about $0.4-0.6 \mathrm{~mm}$ long and $0.6-0.8 \mathrm{~mm}$ wide, standing at an obtuse or right angle with polyp stalk about $0.6-1 \mathrm{~mm}$ long. Anthocodial armature in eight double rows, $4-5$ in a row. One of the outermost pair larger and extends far beyond polyp head; its projecting tip thickly covered with upwarddirecting prominent warts. Shorter lower points in obtusely converging $3-4$ pairs, sometimes in closely disposed transverse rows, apparently suggestive of 'pseudo-crowns.' S.B. strongly developed, composed of 4 or more strongly spinose spindles up to $3 \mathrm{~mm}$ long, more than one of which project for $0.4-1$ 
$\mathrm{mm}$ beyond polyp head. Tentacles with simple rodlike spicules up to $0.05 \mathrm{~mm}$ long, closely disposed in two rows. On ventral side of polyp stalk are large accessory spicules, about $0.6-0.7 \mathrm{~mm}$ long, closely arranged obliquely. Anthocodial formula:

$$
I V=1 P+(3-4) p+0 \text { Cr+strong S.B. }+2 M .
$$
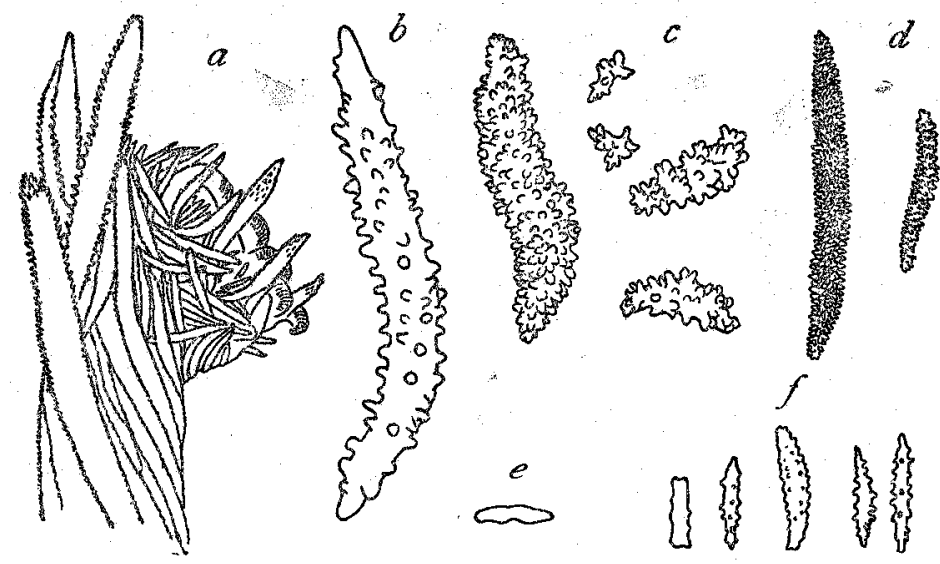

Fig. 5. Dendronephthya aculeata KÜKTH. $a$, Polyp; $b$, uppermost point; $c$, spicules from lower cortex; $d$, spicules from upper cortex; $e$, tentacle spicule; $f$. spicules from canal-walls. $(a, c, d, f \times 35, b, e \times 150)$

On cortex of branches and twigs are rather small spindles about $0.6 \mathrm{~mm}$ long, with numerous close-set conical warts; in foliaceous branches however attaining as long as $4 \mathrm{~mm}$. On basal cortex are smaller spindles, which pass to very tiny stars with rounded stronger warts, about $0.05-0.7 \mathrm{~mm}$ across. In canal-walls there are many flat spindles or discs with blunt warts; $0.17 \times 0.03$ $\mathrm{mm}, 0.26 \times 0.05 \mathrm{~mm}, 0.37 \times 0.05 \mathrm{~mm}$.

Coloring. Stem and branches white, polyp head and upper part of S.B. dark red, paler towards polyp stalk where it is orangish to yellow.

Locality. Kii-ôsima. 1940. S. Sakaguchi leg.

Previously recorded from Nagasaki (Japan) and Mindoro (Philippines).

\section{Dendronephthya spinifera (HOLM)}

(Fig. 6)

Spongodes spinifera, HOLM (1895, p. 37), HICKSON (1903, p. 485).

Dendronephthya spinifera, KüKENTHAL (1905, p. 567), ROXAS (1933, p. 436), MACFADYEN. $(1936$, p. 63). 
A small fragment, consisting only of terminal branches in a hemispherical contour, measures about $2.9 \mathrm{~cm}$ in height and $3.2 \mathrm{~cm}$ in maximum expanse. Most of the polyparium and sterile stalk are missing. However the spiculation of polyps as well as its coloration exactly corresponds with former descriptions of D. spinifera, which is hitherto unknown from Japan.

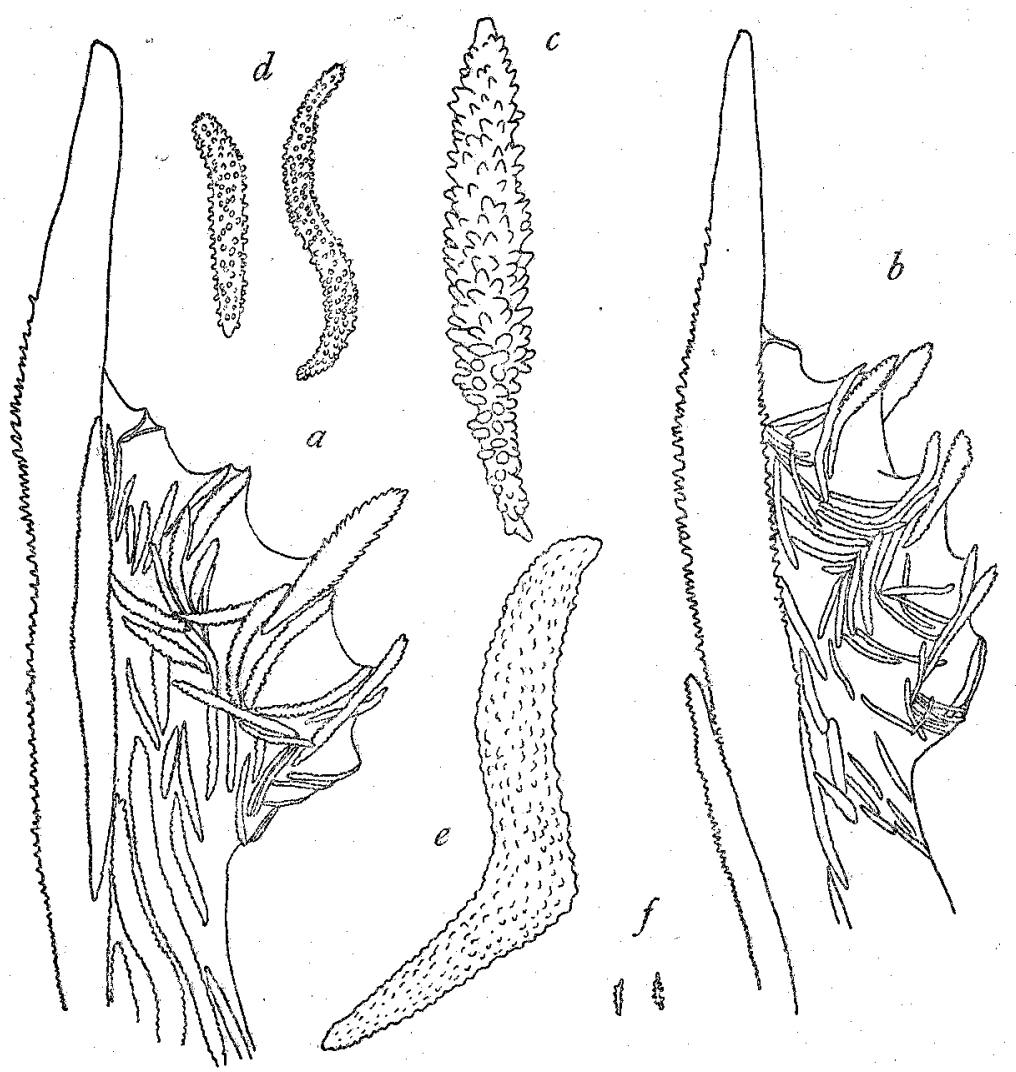

Fig. 6. Denaronephthya spinifera (HOLM, $a, b$, Polyp; $c$, uppermost point spicule; $d$, spindles from upper cortex; $e_{3}$ curved spindle from canalwalls; $f$, flat rod from canal-walls. $(a, b, d, f \times 35, c, e \times 80)$

Polyps compactly massed in a group of 5-12. Polyp head standing at a very obtuse angle with long stalk about $0.6-1 \mathrm{~mm}$ long, mostly elongated dorsoventrally and somewhat compressed laterally, measuring about $0.5 \mathrm{~mm}$ long and $1.2 \mathrm{~mm}$ wide. Anthocodial armature in eight widely separate points, consisting of 4 to 6 in three lateral rows and 1 to 4 in each row on dorsal and ventral sides. One or a pair of outermost points in lateral rows considerably larger than the rest and project for $0.5 \mathrm{~mm}$ long beyond polyp head. Intermediate spicules usually absent. S.B. composed of 3 to 7 large spindles, 
of which one or two may be as long as $3.5 \mathrm{~mm}$, and strongly project out of polyp head for about $0.7-1 \mathrm{~mm}$ long; projecting tip more or less spinose basally but almost smooth distally. Anthocodial formula :

$$
\mathrm{IV}=1 \mathrm{P}+(4-6) \mathrm{p}+0 \mathrm{Cr}+\text { very strong S.B. }+0 \mathrm{M}
$$

Cortical spicules of terminal branches are slender spindles mostly less than $1.5 \mathrm{~mm}$ in length, covered with close-set small rounded warts. Canalwalls thickly filled with plump spindles with low warts, up to $2.5 \mathrm{~mm}$ long and and $0.26 \mathrm{~mm}$ wide; many tiny, toothed flat rods, at most $0.05-0.1 \mathrm{~mm}$ long, are also found.

Coloring. General color of polyps is brilliant coral-red, projecting tips of S.B. often whitish and cortex of branches white.

Locality. Tomioka, Amakusa Island (Kyusyu).

Previously recorded from Viti Islands, Great Barrier Reef, Maldive Archipelago and Philippines.

\section{DivaricATAE}

\section{Dendronephthya japonica KUKENTHAL.}

(Fig. 7 ; Plate IX, Fig. 8)

Dendronephthyja japmica, KürkeNTHAI. (1905, p. 576), THOMSON \& MACKINNON (1910, p. 185; THOMSON \& DEAN (1931, p. 110).

A dark red, divaricate colony, about $14 \mathrm{~cm}$ in height of which about onethird is sterile stalk without stolons. Polyparium flattened in one plane, irregular in outline. Another fragment consisting only of a part of terminal branches, about $2.5 \mathrm{~cm}$ long and $4 \mathrm{~cm}$ wide.

Polyps in groups of 3-10 at ends of diverging twigs loosely located on surface of branches and stem. Polyp head large, rounded, about $0.55-0.7 \mathrm{~mm}$ long and $0.7-0.8 \mathrm{~mm}$ wide, mostly standing at a right or acute angle with a very slender stalk up to $2 \mathrm{~mm}$ long. Point spicules numerous in each row, larger downwards, the number of spicules in each row greatly varies from 6 to 12. At top of space between each point a number of small rodlike spicules are longitudinally or obliquely disposed, so that the distinction between point, tentacle and intermediate spicules may be almost impossible. S.B. composed of 3-7 strong spindles with smaller accessory spicules of which one or two project above polyp head for abont $0.35-0.6 \mathrm{~mm}$ long. Anthocodial formula : 


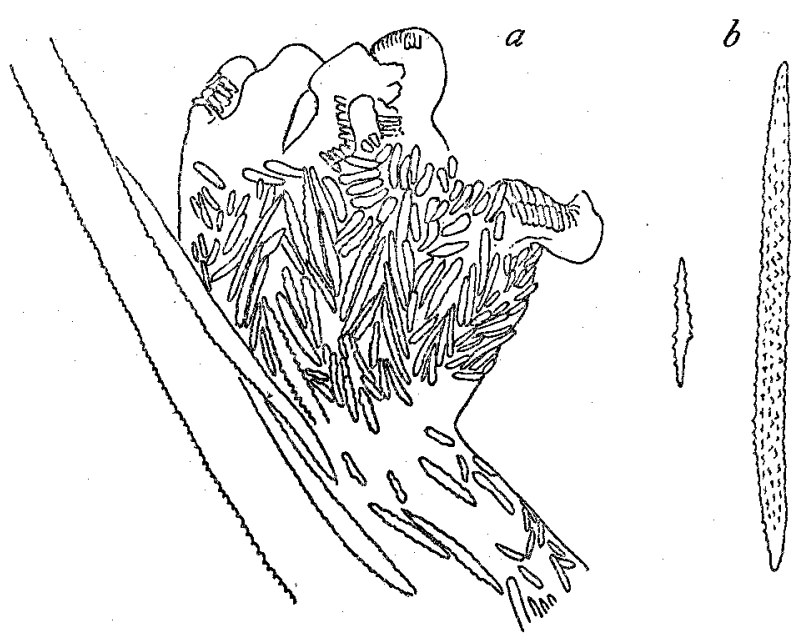

Fig. 7. Dendronephthya japonica KüKTH. $a$, Polyp; $b$, spindles from upper cortex. $(a \times 35, b \times 55)$

$I I=(6-12) p+0 \mathrm{Cr}+$ very strong $\mathrm{S} . \mathrm{B}+$ many $\mathrm{M}$

Cortex of branches loosely and irregularly disposed with very slender spindles up to $3 \mathrm{~mm}$ long and, $0.16 \mathrm{~mm}$ wide, between which much smaller dentate spindles occur abundantly. Canal-walls devoid of spicules.

Coloring. Polyps ochre-yellow, anthocodial and tentacular spicules yellowish white, S.B. and twigs dark red and branch cortex reddish. Stalk dark red.

Localities. Seto and Nada, Kii Coast. 1950. T. YAmanoto leg.

Previously recorded from S. W. of Japan and Roma Island (Malay Archipelago).

\section{Dendronephthya palmata n. sp.}

(Fig. 8; Plate IX, Fig. 9)

Divaricate. A somewhat rigid, treelike colony with a polyparium flattened in one plane and of a roughly circular outline, $10 \mathrm{~cm}$ in height and $9 \mathrm{~cm}$ in maximum expanse. Seven lowest branches encircling stem decidedly foliaceous, directed downwards. Sterile stalk 2-3 cm long, about one-fourth of total height and with flat base without stolons, having a diameter of about $2 \mathrm{~cm}$ : Polyps crowded at ends of short-stalked twigs borne rather loosely on main stem and branches which ramify in a palmate fashon. 
Polyps in a group of 3 to 10 . Polyp head about $0.6 \mathrm{~mm}$ long and $0.76-$ $0.88 \mathrm{~mm}$ wide, making an obtuse angle with plump stalk, shorter than $0.5 \mathrm{~mm}$. Anthocodial armature in eight double rows of 6-7 paired spicules; all of subequal length, about $0.18-0.25 \mathrm{~mm}$ long and $0.016-0.018 \mathrm{~mm}$ wide, with few warts and outermost pair not projecting beyond polyp head. 2-4 intermediate spicules, about half as long as point spicules, occur downwards between points. Tentacles with 8 pinnules on each side and with a few flat disc-like red spicules or none at base of aboral side. S. B. spicules relatively short, about 1.5$2.5 \mathrm{~mm}$ long and spinose towards projecting tips, up to $0.5 \mathrm{~mm}$ long. Polyp stalk armoured with slightly warted spindles arranged in two regular rows on each side. Anthocodial formula:

$$
\mathrm{II}=(6-7) \mathrm{p}+0 \mathrm{Cr}+\text { strong S.B. }+(1-2) \mathrm{M}
$$
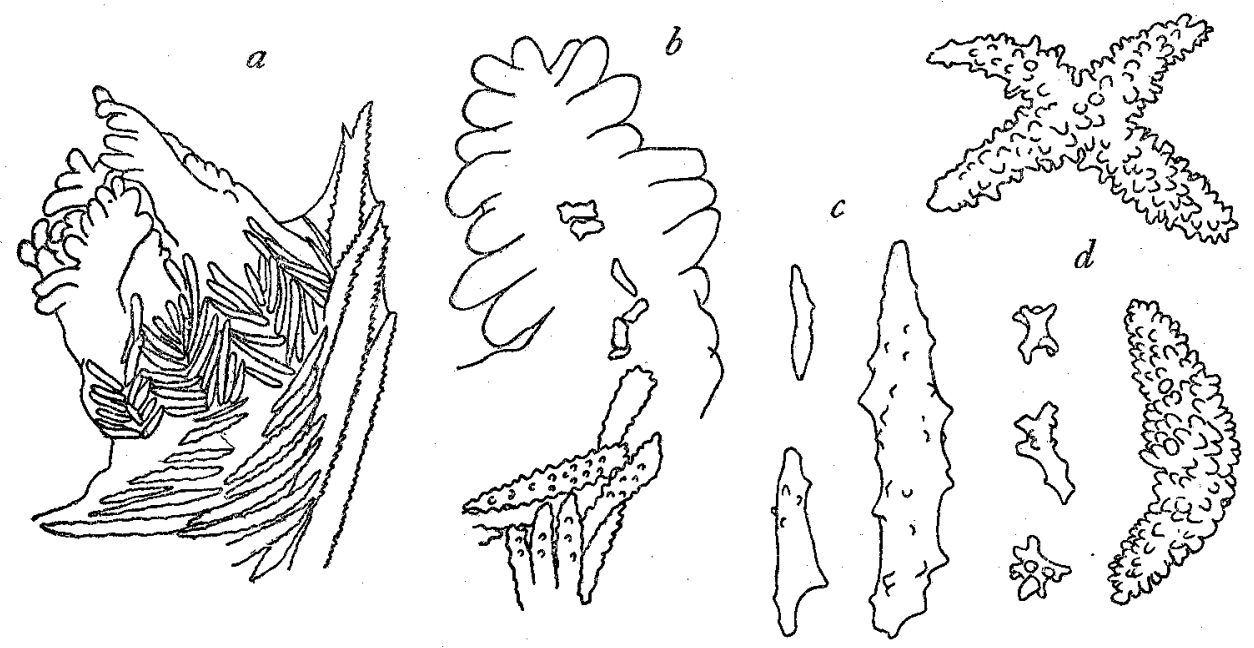

Fig. 8. Dindronephihya palmata n. sp. $a$, Polyp; $b$, arrangement of spicules in tentacle; $c$, spicules from canal-walls; $d$, spicules from basal cortex. $(a \times 35, c, d \times 55, b \times 70)$

On cortex of upper branches are white or red slender warty spindles, up to $4 \mathrm{~mm}$ long and $0.18 \mathrm{~mm}$ wide, loosely and irregularly disposed. On basal cortex are yellowish white spindles with prominent warts, up to $2.3 \times 0.23 \mathrm{~mm}$, triradiates and quadriradiates, and also numerous capstan-like or irregularshaped smaller bodies, about $0.08-0.2 \mathrm{~mm}$ across. Canal-walls thickly filled with spindles and triradiates with few but prominent warts; $0.3 \times 0.06 \mathrm{~mm}, 0.6 \times$ $0.11 \mathrm{~mm}, 1.5 \times 0.018 \mathrm{~mm}$. No smaller antler-like flat bodies exist.

Coloring. Polyp and S. B. spicules blood-red, but polyps themselves yellow, branch cortex white mottled with red spicules in places, stalk ochre-yellow.

Locality. Tanabe Bay.

Remarks. In general appearance of the colony and polyps, this specimen 
comes near to D. microspiculata of KüKENTHAL's rigidangroup, but the shortness of stalk and the difference of polyp spiculation are so distinctive as to be compelled to establish a new species.

\section{Dendronephthya furcata n. sp.}

(Fig. 9; Plate IX, Fig. 10)

Divaricate. From a blunt base bearing many short stolons, a graceful red-colored colony arises to a height of $12 \mathrm{~cm}$. Sterile stalk, occupying about one-third of total height, very rigid and shrunken with an indication of deep longitudinal furrows. Polyparium markedly flattened, but not uniform in contour, having a broadest expanse of $7 \mathrm{~cm}$. Main stem stands erect and gives rise to three side branches which divide and subdivide into a number of terminal branches and twigs. Widely divergent twigs are borne loosely on bare surface of stem and branches. Lowest two branches broadly expanded with a series of small foliate projections turned downwards.
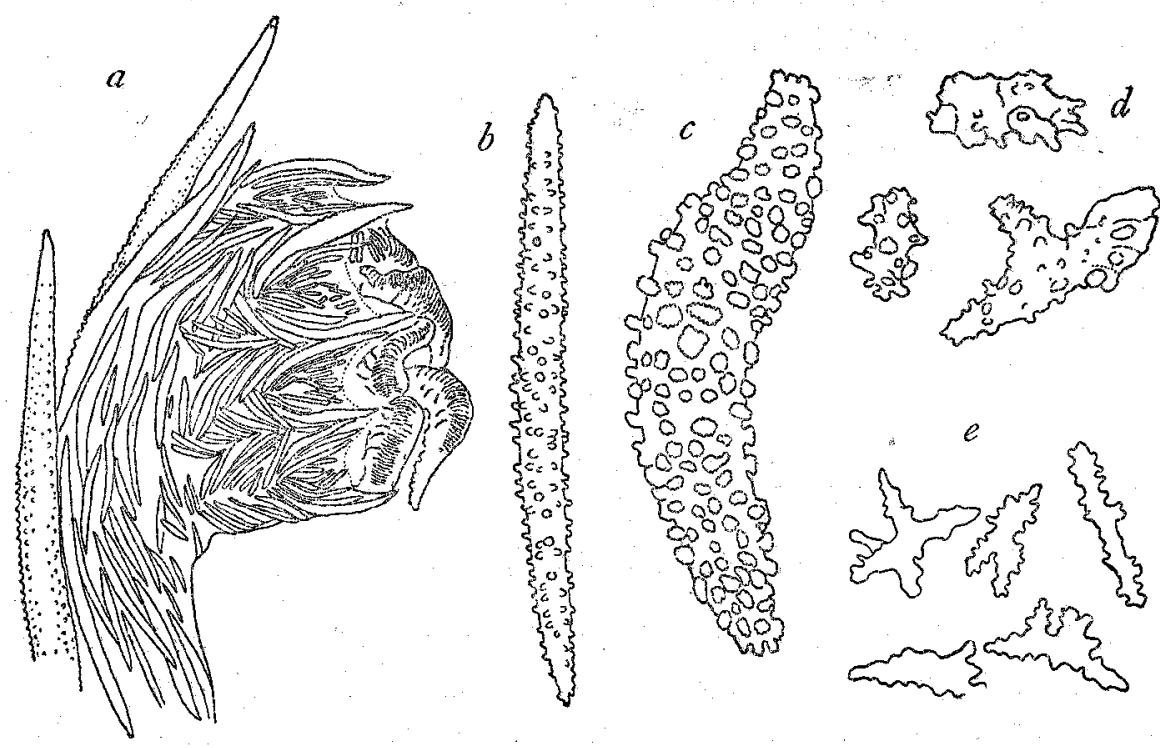

Fig. 9. Dendroneplithya furcata n. sp. $a$, Polyp; $b$, spindle from upper cortex; $c, a$, spindle and derivatives from basal cortex; $e$, flat spicules from canal-walls. $(a \times 35, b-e \times 55)$

Polyps usually in groups of $3-5$, sometimes singly, at ends of long, slender, divergent twigs. Polyp head relatively large, about $0.8 \mathrm{~mm}$ long and $0.8-1 \mathrm{~mm}$ wide, more or less Jaterally compressed, and making an obtuse angle with 
slender polyp stalk about 1-1.5 mm long. Anthocodial armature in eight regularly converging double rows, about 6 in a row. Uppermost one larger, spinose, sharply tipped and extends beyond polyp head. Between points are thickly disposed numerous small intermediate spicules, as many as 15 , converging downwards. Tentacles considerably large, heavily armoured with small, toothed, oval or rodilike, reddish spicules, not forming any regular row. S. B. spicules, $4 \mathrm{~mm}$ long in largest one, finely and thickly tuberculate almost towards the free tip which projects for about $0.5-1 \mathrm{~mm}$ beyond polyp head. Polyp stalk densely disposed with red spindles lying transversely. Anthocodial formula:

$$
\mathrm{III}=1 \mathrm{P}+5 \mathrm{p}+0 \mathrm{Cr}+\text { strong S.B. }+ \text { many } \mathrm{M}
$$

On cortex of main stem and branches are transversely disposed red or reddish white spindles with simple conical warts, up to $5 \mathrm{~mm}$ long and $0.35 \mathrm{~mm}$ wide. On basal cortex are shorter, straight or curved, plump, reddish spindles with compound warts, up to $1.5 \times 0.35 \mathrm{~mm}$, mostly $1.0 \times 0.18 \mathrm{~mm}$, and their derivatives. Canal-walls contain simply toothed, colorless spindles, up to $0.25 \mathrm{~mm}$ long, mingled with less-warted, almost flat triradiates and stellate forms.

Coloring. All polyps, terminal twigs and lower foliaceous branches red, cortex of main stem, branches and stalk pale red.

Locality. Tanabe Bay.

Remarks. In the mode of branching and anthocodial armature this specimen approaches to $D$. depressa and $D$. rosea, recorded by KüKENTHAL (1896) from Ternate, both belonging to KürENTHAL's rigida-group of the Divaricatae, and also D. Alabellifera of the Umbellatae, known from Japan. But it does not agree with either of them in detailed structure of spiculation as well as in coloration.

\section{Dendronephthya alba n. sp.}

(Fig. 10; Plate X, Fig. 26)

A very rigid, entirely glistening white colony of a markedly spiny appearance. Polyparium distinctly flattened, not uniform in outline and measures about $6.5 \mathrm{~cm}$ in length and $6 \mathrm{~cm}$ in maximum breadth. Main branches ended in rounded contour, with densely crowded twigs, and widely apart from one another. Lowest branches, more than 5 in number, markedly foliaceous, but not forming a continuous collar around stem. Sterile stalk, about one-third of total height of the colony, very rigid, columnar, and with a flat base bearing short stolons; its height as well as basal diameter about $2.5 \mathrm{~cm}$.

Polyps in groups of 3-10 at ends of twigs. Polyp head compressed late- 
rally, about $0.7 \mathrm{~mm}$ long and $0.8-0.9 \mathrm{~mm}$ wide, making a right or obtuse angle with slender polyp stalk about $1-1.5 \mathrm{~mm}$ long. Anthocodial armature in eight double rows, 6-7 in a row. One of uppermost pair large, hockey-club-like in shape, up to $0.8 \mathrm{~mm}$ long on lateral sides, while at most $0.5 \mathrm{~mm}$ long in two ventral rows, and extends prominently beyond polyp head; the other one about

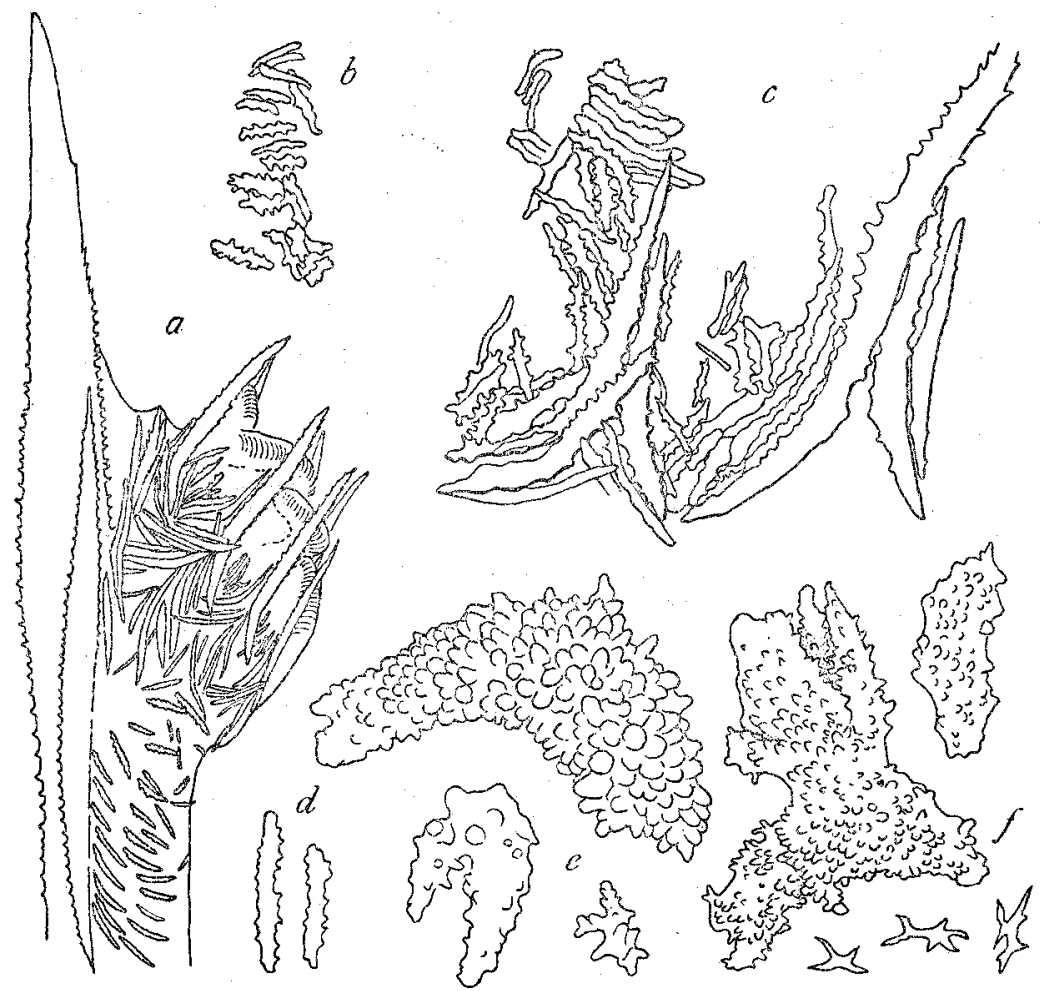

Fig. 10. Dendronephthya alba n. sp. $a$, Polyp; $b$, arrangement of spicules in tentacle; $e$, part of anthocodial armature; $d$, spicules from polyp stalk; $e$, spicules from lower cortex; $f$, warty spicules and antler-like flat bodies from canal-walls. $(a \times 35, e, f \times 55, b-a \times 100)$

one-third as long as the larger one, up to $0.26 \mathrm{~mm}$. Lower points longer downwards up to $0.35 \mathrm{~mm}$ long. Between points there are more than 3 pairs of intermediate spicules, about $0.05-0.18 \mathrm{~mm}$ long. Tentacles very long, with closeset small spicules, about $0.05 \mathrm{~mm}$ long at base, transversely arranged. S.B. very strongly developed; usually only one spicule, up to about $4 \mathrm{~mm}$ long and $0.33 \mathrm{~mm}$ wide, predominates and projects beyond polyp head for over $1 \mathrm{~mm}$; it is colorless, opaque and densely covered with small conical warts, except at free tip where it is smooth. Ventral side of polyp stalk obliquely disposed with 
many small toothed rods of approximately the same length, mostly $0.15 \times 0.02 \mathrm{~mm}$. Anthocodial formula :

$I V=1 P+(5-6) p+0 \mathrm{Cr}+$ very strong S.B. + many $M$

In cortex of upper stem and branches are numerous slender warty spindles up to $3 \mathrm{~mm}$ long, arranged transversely. In cortex of stalk are small plump spindles, triradiates, multiradiates and stellate forms with prominent rounded warts, of various sizes ranging from $0.2 \mathrm{~mm}$ to $2 \mathrm{~mm}$ long. Canal-walls contain all similar spicules, less than $1.5 \mathrm{~mm}$ long, together with antler-like flat bodies up to $0.16 \mathrm{~mm}$ long.

Coloring. Glistening white all over.

Locality. Kii-ôsima. 1941. S. SAKaguchi leg.

Remarks. This form is to be referred to KünENTHAL's cervicornis-group of the Divaricatae by its irregular contour and distinctly flattened polyparium. Yet it does not agree with any of the known species within this group, especially in the very peculiar spiculation and in the glistening whiteness of the whole colony.

\section{Dendronephthya palaoensis n. sp.}

(Fig. 11; Plate X, Fig. 11)

A handsome flexible, treelike colony, about $12 \mathrm{~cm}$ in height and $9 \mathrm{~cm}$ in maximum breadth. Sterile stalk flaccid, columnar, less than one-fourth of total height of the colony, and at base forms a membranous expansion terminating into a number of extremely elongate and ramified stolons entangled with debris and sands. Polyparium divaricate in an oval outline and decidedly flattened in one plane. Polyp-bearing twigs borne on all surface of erect stem and branches equally short-stalked, about $2 \mathrm{~mm}$ long, and loosely spaced. Lowest branches, 5 in number, slightly foliaceous, but do not form a complete collar around stem.

Polyps in groups of 3 to 10 at ends of twigs. Polyp head laterally compressed, about $0.58 \mathrm{~mm}$ long and $0.82 \mathrm{~mm}$ wide, standing at an obtuse angle with rather long, stout polyp stalk, often over $1 \mathrm{~mm}$ long. Anthocodial armature consists of eight widely spaced double rows, 3 in laterals on either side and each one on dorsal and ventral side, each row consisting of 3-5 pairs of almost smooth, rather large, slender spindles. Uppermost one or a pair in three lateral rows longer (up to $0.6 \mathrm{~mm}$ long) than that in ventrals (about $0.45 \mathrm{~mm}$ long) and strongly project beyond polyp head. Usually no intermediate spicules occur between points, but if any, very slender, about $0.25 \mathrm{~mm}$ long and situated close to tips of uppermost points. Tentacles long, apparently devoid of spicules. 
Ventral side of polyp stalk below head almost nude. S.B. strongly developed and composed of one or two strong, finely-warted, bicolored spindles, up to $4 \mathrm{~mm}$ long and $0.35 \mathrm{~mm}$ wide, together with several smaller, wholly red, accessory spicules, the largest one of which projects for over $1 \mathrm{~mm}$ long beyond polyp head, and colored yellow upwards and red downwards. Anthocodial formula :

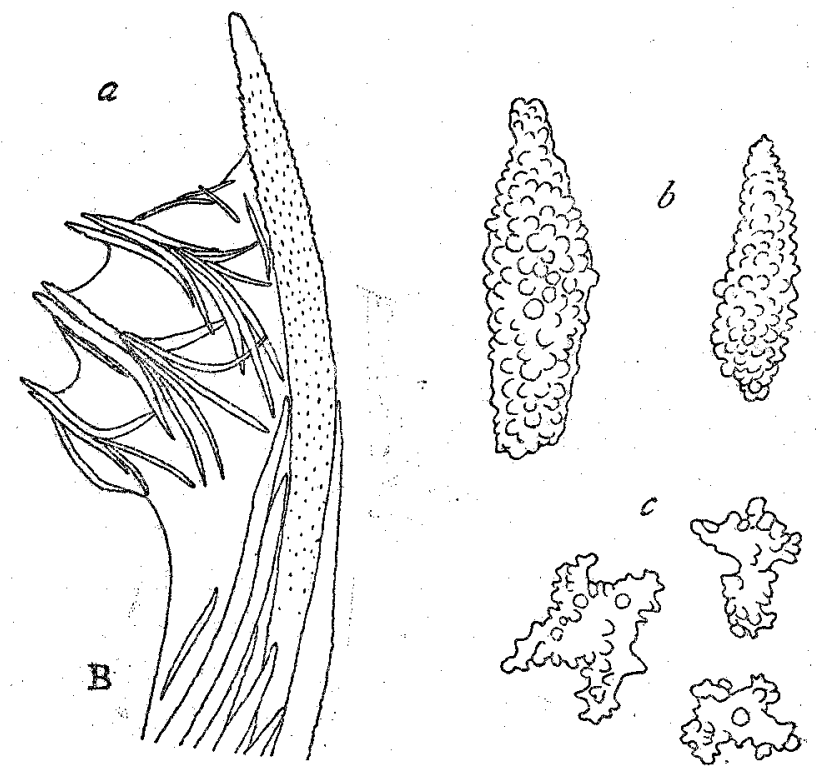

Fig. 11. Dendronephthya palaoensis n. sp. $a$, Poîyp; $b$, spindles from upper part of stalk; $c_{\eta}$ spicules from lower part of stalk. $(a \times 35, b, c \times 55)$

IV $=1 \mathrm{P}+(2-4) \mathrm{p}+0 \mathrm{Cr}+$ very strong S.B.+ $(0$ or 1$) \mathrm{M}$

On cortex of branches and twigs are irregularly and sparsely disposed strongly-warted spindles, either white or red in color, up to $6 \mathrm{~mm}$ long, but mostly about $2 \mathrm{~mm}$ long. Spiculation of upper portion of stalk is similar to the above. At its lower portion and also stolons are, however, all smaller, irregular-shaped bodies with rounded warts, up to $0.35 \mathrm{~mm}$ long. Canal-walls free from spicules.

Coloring. Polyp head (both anthocodial spicules and upper portion of S.B.) yellow, polyp stalk and twigs blood-red, branch aud stalk reddish white, due to the combined occurrence of red and white spicules. Base of stalk with stolons greyish with reddish hue.

Locality. Korror Island of the Palao Islands group, on coral platform. 1937. T. Yamanouchi leg.

Remarks. The anthocodial architecture of the present specimen appears like that of $D$. marenzelleri of cervicornis-group of the Divaricatae, recorded 
from Karoline Islands, and also somewhat of $D$. kollikeri of the Glomeratae, recorded also from Palao Islands. However, the grow th form, as mentioned above, shows to be referred to rigida-group of the Divaricatae. Within this group, however, the specimen does not agree with any of the species included.

\section{Dendronephthya fil igrana KüKENTHAL}

(Fig. 12; Plate XI, Fig. 27)

Divaricate, belonging to KüKENTHAL's rigida-group. A somewhat flexible colony, about $11 \mathrm{~cm}$ long and $8.5 \mathrm{~cm}$ wide. Polyparium consists of a tall main stem and three large side branches of similar length, horizontally arising from stem, and flattened in one plane. Lowest branches at top of stalk small and slightly foliaceous. Sterile stalk rather rigid, tall, cylindrical, about $4 \mathrm{~cm}$ long and bears many long stolons around its lower half.

Polyp head, about $0.5-0.9 \mathrm{~mm}$ long and $0.7 \mathrm{~mm}$ wide, standing at a very obtuse angle with long, tapering stalk up to $2 \mathrm{~mm}$ long. Anthocodial armature consists of eight double rows of very steeply converging spindles, 2 or 3 in lateral rows and 1 or 2 in dorsal and ventral rows, instead of 5-6 in laterals as described by Kükenthal (1906, p. 44). Uppermost pair larger, spinose and extend freely far out of head, but mostly covered with epithelium; lower points more slender and almost smooth. Intermediate spicules absent. Tentacles

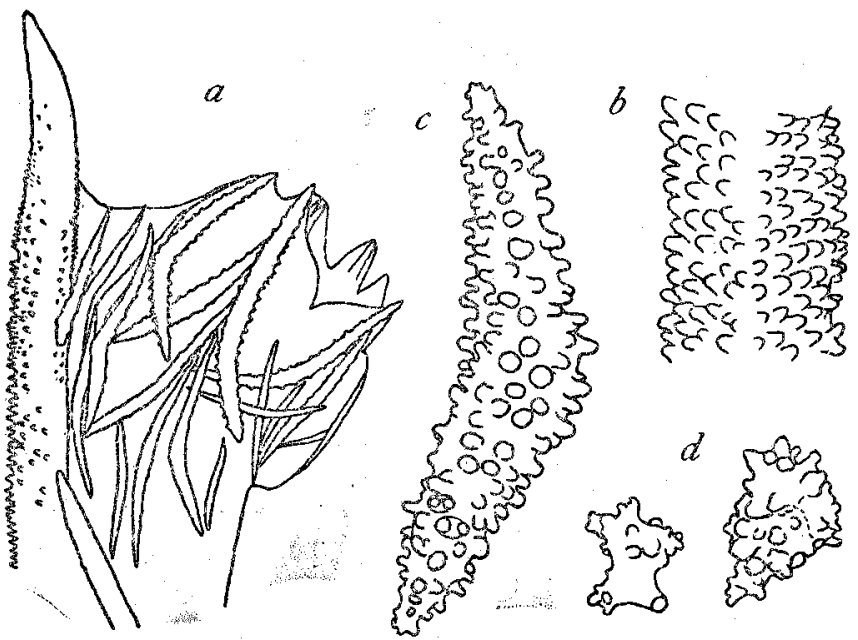

Fig. 12. Dendronephthya filigrana KÜKTH. $a$, Polyp; $b$, part of spindle from upper cortex, showing the transverse arrangement of conical warts; $c$, spindle from upper part of stalk; $d$, stellate forms from lower part of stalk. $(a \times 35, c, d \times 55, b \times 70)$ 
with colorless, slightly toothed, flat rods, about $0.08 \mathrm{~mm}$ long at base, arranged in 2 rows. S.B. spicules, up to $5.5 \mathrm{~mm}$ long, finely spinose, and only one projects for about $1 \mathrm{~mm}$ long or more. Anthocodial formula :

$$
\mathrm{IV}=(2-3) \mathrm{p}+0 \mathrm{Cr}+\text { very strong S.B. }+0 \mathrm{M}
$$

In upper cortex are very large spindles, up to $6 \mathrm{~mm}$ long and $0.5 \mathrm{~mm}$ wide, covered with rounded or conical warts regularly arranged in transverse rows. In stalk cortex are shorter curved spindles up to $1 \mathrm{~mm}$ long, becoming downwards to almost globular stellate forms with prominent warts, up to $0.26 \mathrm{~mm}$ across. Canal-walls devoid of spicules.

Coloring. Stalk straw-colored, stem and branches white. Polyps and S.B. ochre-yellow.

Locality. Off Minabe, Kii coast, 100-200 m. March 1950.

Previously recorded from Misaki (Japan).

\section{Dendronephthya divaricata (GRAY)}

(Fig. 13; Plate XI, Fig. 29)

Spongodes divaricata, GRAY (1862, p. 29; 1869, p. 128).

Dendronephthya divaricata, KǘKENTHAL (1905, p. 588), THOMSON \& MACKINNON (1910, p. 185), ROXAS (1933, p. 443).

A small but complete colony, about $4.5 \mathrm{~cm}$ in total length, of which about one-half belongs to sterile stalk. Polyparium with a regular rounded contour of about $1.3 \mathrm{~cm}$ in diameter and not flattened laterally. A few short branches at top of long cylindrical stem give off horizontally a number of diverging side branches of similar length. Lower branches foliaceous at top of stalk. Staik cylindrical, flabby and bears a few slender stolons at base.

Polyp head stands at an obtuse or right angle with long stalk up to $1 \mathrm{~mm}$. Anthocodial armature in eight double rows, mostly 5 in a row; outermost pair larger, about $0.3 \mathrm{~mm}$ long and slightly extend beyond polyp head. S.B. strongly developed, composed of three or more finely warted spindles, as long as $2.5 \mathrm{~mm}$, with almost smooth tip extending for about $0.6 \mathrm{~mm}$ long beyond polyp head. Tentacle spicules of colorless, slightly toothed flat rods, about $0.07 \mathrm{~mm}$ long, closely packed in two rows. Anthocodial formula:

$$
\text { IV }=1 \mathrm{P}+(3-5) \mathrm{p}+0 \mathrm{Cr}+\text { strong S.B. }+(1-2) \mathrm{M}
$$

In upper cortex are colorless, slender, mostly curved spindles with fine warts, up to $2 \mathrm{~mm}$ long. In basal cortex are white or rosy, plump spindles with strong warts, about $0.5 \times 0.09 \mathrm{~mm}$, becoming sparse downwards. In addition many rosy or uncolored, small triradiates, quadriradiates and irregular forms, about

$$
-143-
$$




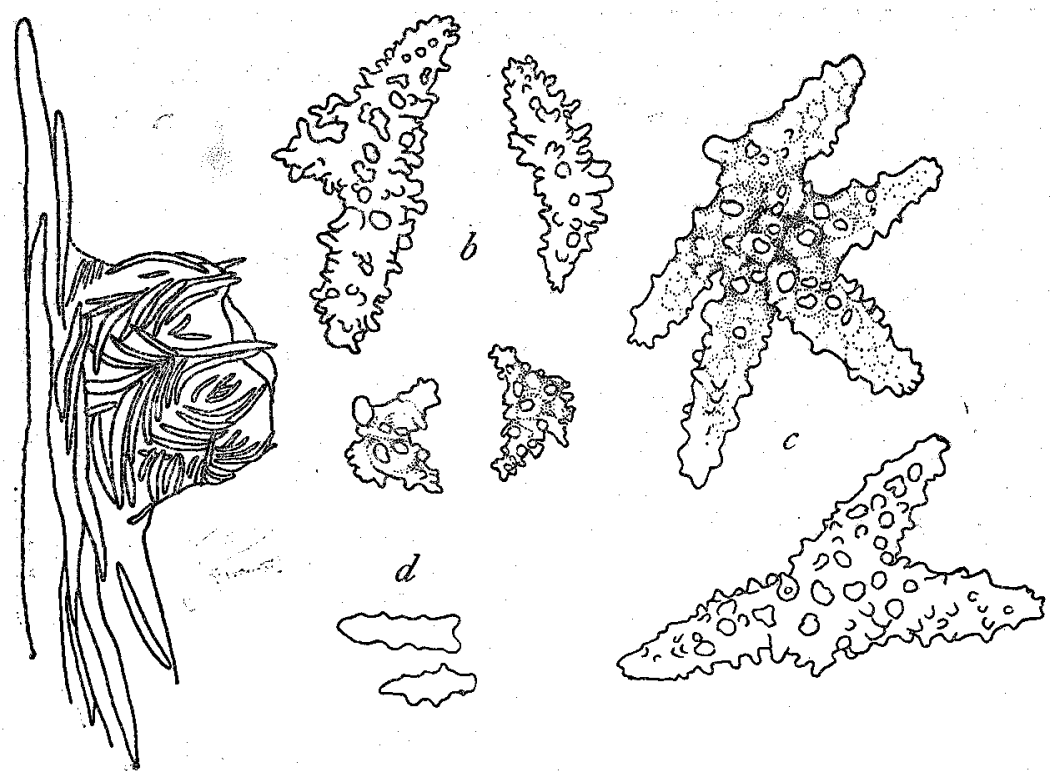

Fig. 13. Dendronephthya divaricata (GRAY). $a$, Polyp; $b$, spicules from lower cortex; $c$, spicules from canal-walls; $d$, tentacle spicules. $(a \times 35, b, c \times 70, d \times 150)$

0.05-0.2 mm long, are found. Canal-walls contain mostly stout triradiates, quadriradiates and multiradiates with compound warts, up to $1.2 \times 0.17 \mathrm{~mm}$.

Coloring. Wholly white, except at lower half of stalk where it is tinged with a rosy hue. Polyp itself slightly cream-colored.

Locality. Tanabe Bay, $10-20 \mathrm{~m}$.

Previously recorded from New Guinea, Philippines and Indian Ocean (Providence and Mauritius).

\section{Dendronephthya golgatha n. sp.}

(Fig. 14; Plate X, Fig. 12)

A flexible treelike colony of irregular branchings. In a complete specimen, about $10 \mathrm{~cm}$ high, polyparium is distinctly flattened in one plane, but not uniform in contour, and stalk about one-fifth of total height of the colony. In another fragment without stalk, polyparium not distinctly flattened and irregular in outline. In both specimens, upper branches are cylindrical, rather uniform in diameter and wrinkled transversely, and terminate in slightly diverging twigs; the mode of branching is thus suggestive of the divaricate form of the Glomeratae. A number of short polyp-bearing twigs are borne sparsely on all surface 
of stem and branches. Lowest branches, numerous in number, at top of stalk distinctly foliaceous, but do not form a collar. Sterile stalk cylindrical, wider than high, and bears short stolons around flat base, about $2.5 \mathrm{~cm}$ in diameter.

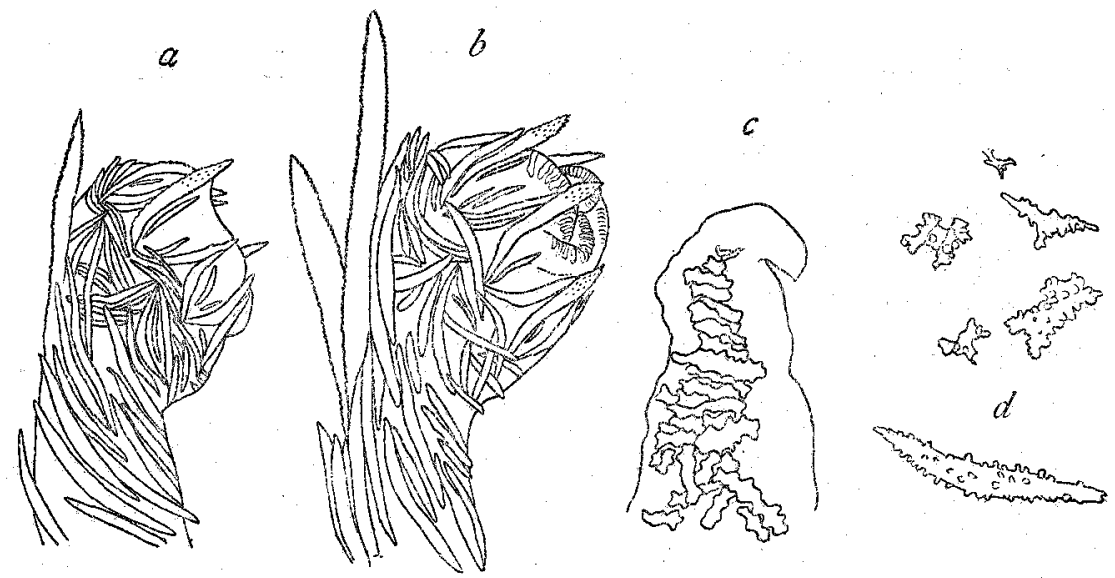

Fig. 14. Dendronephthy $a$ golgotha n. sp. $a, b$, Polyp; $c$, arrangement of spicules in tentacle; $d$, spicules from stalk cortex. $(a, b, d \times 35, c \times 100)$

Polyps in groups of 5-10 at ends of twigs. Polyp head small, about 0.35-0.45 $\mathrm{mm}$ long and $0.5-0.6 \mathrm{~mm}$ wide, making an obtuse angle with polyp stalk, shorter than $1 \mathrm{~mm}$. Anthocodial armature in eight points consisting of a single pair of highly projecting spindles, often associated with a much smaller one at its base. Below points there are 4-6 'pseudo crown' spicules, of which 1 or 2 are horizontally disposed, and 3 or 4 in converging pairs below. 1-3 much smaller intermediate spicules occur between points. Tentacles with red, toothed flat rods, about $0.05-0.1 \mathrm{~mm}$ long, closely disposed in two rows. S.B. projects beyond polyp head for up to $1 \mathrm{~mm}$ long, mostly $0.3-0.6 \mathrm{~mm}$ long; its spicules rather short, at most $2 \mathrm{~mm}$ long and $0.15 \mathrm{~mm}$ wide, and finely spinose throughout. Polyp stalk densely disposed with large spindles on ventral side. Anthocodial formula:

$$
\mathrm{VI}=1 \mathrm{P}+(4-6) \mathrm{Cr}+\text { strong S.B. }+(0-1) \mathrm{M}
$$

On cortex of branches are slender spindles with minute warts transversely arranged; $0.3 \times 0.04 \mathrm{~mm}, 0.8 \times 0.07 \mathrm{~mm}, 1.1 \times 0.07 \mathrm{~mm}$. On cortex of stalk are smaller spindles less than $0.7 \mathrm{~mm}$ long, but mostly much more tiny star-shaped bodies about $0.08-0.3 \mathrm{~mm}$ across. Canal-walls devoid of spicules.

Coloring. Branch and stalk white, polyp and S.B. spicules blood-red, while polyps themselves yellowish white.

Locality. Kii-ôsima. 1940. S. SaKÁguchi leg.

Remarks. The general appearance of the colony as well as the anthocodial armature approaches closely to $D$. suensoni (HoLm) recorded from Japan. 
But it differs from the latter in the absence of spicules in canal-walls and in the smallness of polyps with a relatively short stalk.

\section{Dendronephthya cervicornis (WRIGHT \& STUDER)}

(Fig. 15; Plate X, Fig. 13)

Spongodes cervicornis, WRIGHT \& STUDER (1889, p. 220), HICKSON \& HILES (1900, p. 498).

$S$ p. rhodosticta, WRIGHT \& STUDER (1889, p. 218), HiCKSON \& HILES (1900, p. 498.).

Dendronephthya cervicornis, KÜKENTHAL (1905, p. 592), THOMSON \& HENDERSON (19)9), THOMSON \& DEAN (1931, p. 118), ROXAS (1933, p. 446;.

A very flexible, divaricate colony with slender branchings of no uniform contour, distinctly flattened in one plane. There are in the collection three specimens of which the largest one has a flattened polyparium, about $8 \mathrm{~cm}$ long and $6 \mathrm{~cm}$ wide, the stalk being missing. In the other smaller one, the total height is $6 \mathrm{~cm}$ of which $1.5 \mathrm{~cm}$ is the stalk, about $6 \mathrm{~mm}$ in basal diameter. Lowest branches of both specimens are slightly foliaceous.

Polyps in rather divergent groups of 3 to 8 at ends of twigs. Polyp head about $0.5 \mathrm{~mm}$ long and $0.62 \mathrm{~mm}$ wide, standing at a right angle with stalk shorter than $1 \mathrm{~mm}$. Anthocodial armature consists of only one pair of points, of which one projecting, $0.35-0.5 \mathrm{~mm}$ long, beyond polyp head, and below these

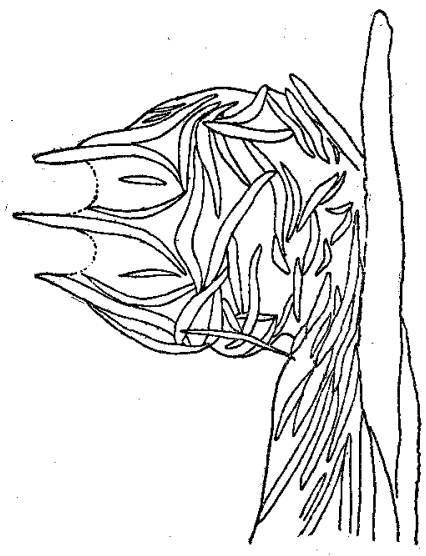

Fig. 15. Dendronephthya cervicornis (WR. \& ST.). Polyp. ( $\times 35)$ usually 2 horizontally disposed and 2 or 3 converging crown spicules; between points usually occurs a single small intermediate spicule or none. Anthocodial formula:

$$
\mathrm{VI}=1 \mathrm{P}+(4-5) \mathrm{Cr}+\text { strong S.B. }+\left(0-\frac{1}{2}\right) \mathrm{M}
$$

Cortical spicules on branches and stalk are irregularly disposed red or reddish white spindles, about $1.7-2 \mathrm{~mm}$ long, with minute warts, often almost smooth in smaller ones. No other kind of spicules is found. Canal-walls apparently devoid of spicules.

Coloring. On the whole purplish-red, becoming paler downwards, dependant on predominance of white spicules there, but polyps themselves are greyish yellow.

Locality. Seto.

Previously recorded from Tahiti, Funafuti, Kei, Lifu and Andaman Islands, and also from Philippines. 
Remarks. The anthocodial spiculation of the present specimens conforms well with that of $D$. cervicornis. The general color scheme and cortical spiculation seem to be somewhat different from previous descriptions. However I feel justified in assigning it to this species, since some slight disagreement in the general color scheme, cortical spiculation and in the proportion of stalk to polyparium seems negligible, as most of former authors recognize.

\section{Dendronephthya decussatospinosa n. sp.}

(Fig. 16; Plate XI, Fig. 25)

A tall divaricate colony of a very unique appearance, about $19 \mathrm{~cm}$ in total height. Stalk very tall, about $15 \mathrm{~cm}$ high, flexible and cylindrical gradually tapering upwards; its diameter is about $1 \mathrm{~cm}$ at top and $2 \mathrm{~cm}$ at base. Base is slightly mutilated, so that it may not be discriminated whether stolons practically occur or not. Polyparium distinctly flattened in a uniform contour wider than high; from an erect main stem two side branches (a longer up and a shorter below) are given off prependicularly on each side. Base of two lowest branches distinctly foliaceous, turned downwards and faced to each other along the long axis of stem.

Polyps in groups of 3-10 at ends of twigs loosely spaced. Polyp head stands at a right angle with polyp stalk about $1 \mathrm{~mm}$ long; its contour roundly depressed, nearly octagonal as seen from above, about $0.6 \mathrm{~mm}$ in diameter and $0.45 \mathrm{~mm}$ in height, if including projecting point spicules also, attaining to $0.7 \mathrm{~mm}$ in height. Anthocodial armature shows eight points, usually crossed over the mouth, each point consisting of a very long, prominently projecting, hockeyclub-like spindle (about $0.6 \mathrm{~mm}$ long) and a much smaller one (about $0.25-0.4 \mathrm{~mm}$ long). Below these points 3 horizontals and $3-4$ converging pairs are closely disposed. Intermediate spicules are mostly only one, but rarely 2 or 3 , its being $0.12 \mathrm{~mm}$ long. Tentacles with elongate rods, up to $0.047 \mathrm{~mm}$ long, arranged bilinearly. S.B. very strongly developed, one or two spicules extending far beyond polyp head for over $1 \mathrm{~mm}$ long, often $1.5 \mathrm{~mm}$ long, with smooth free tip. All these spicules hyaline and finely spinose. Anthocodial formula: $\mathrm{VI}=(1-2) \mathrm{P}+(6-7) \mathrm{Cr}+$ very strong S.B. $+\left(\frac{1}{2}-1\right) \mathrm{M}$

On cortex of main stem and branches are densely disposed short, hyaline spindles with small simple warts, up to $0.8 \mathrm{~mm}$ long and $0.1 \mathrm{~mm}$ wide. On cortex of sterile stalk are closely disposed small, white or rosy, star-shaped warty bodies from $0.2 \mathrm{~mm}$ to $0.9 \mathrm{~mm}$ across; they gradually become larger downwards and at the base a few short spindles are also found. Canal-walls 

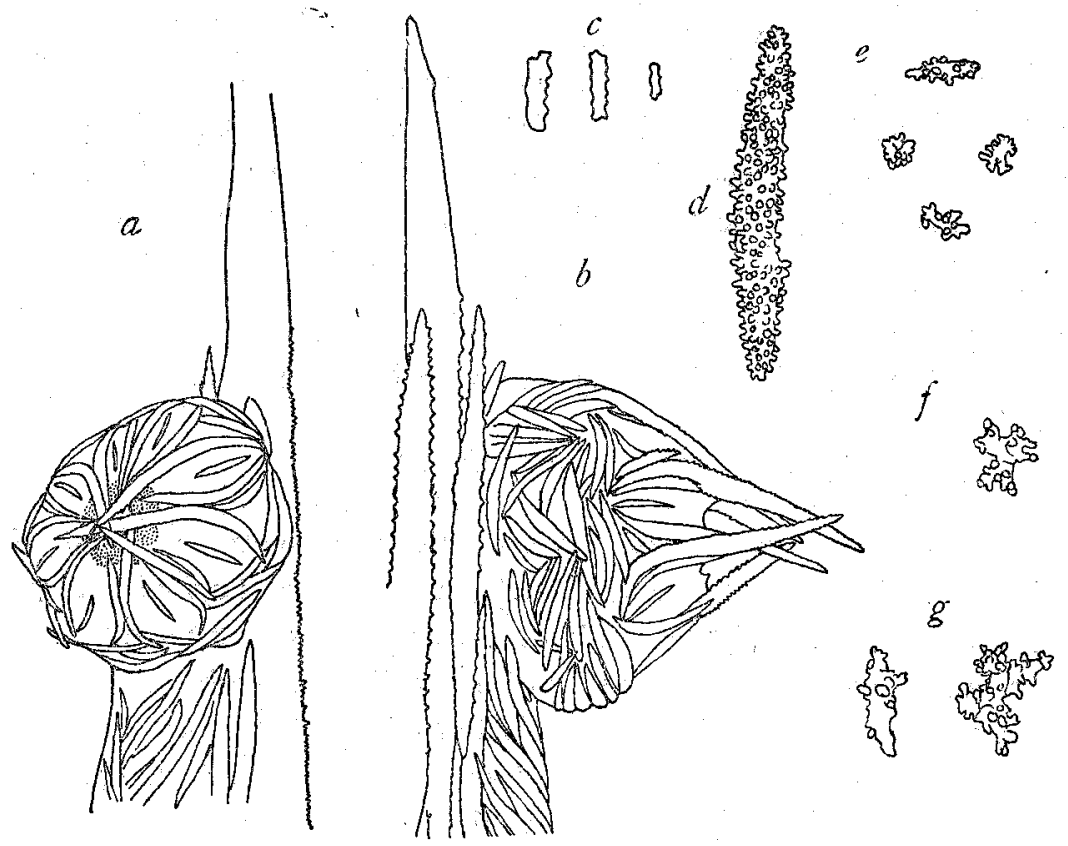

Fig. 16. Dendronephthya decussatospinosa n. sp. $a$, Polyp, ventral view; $b$, polyp, lateral view; $c$, tentacle spicules; $d$, spindle from upper cortex; $e-g$, cortical spicules from upper $(e)$, middie $\{f\rangle$ and lower $(g)$ parts of stalk. $(c \times 150$, all the others $\times 55\rangle$

devoid of spicules, only showing a lozenge-shaped network of solenia.

Coloring. Polyparium wholly grossy-white, sterile stalk pink, paler upwards.

Locality. Seto.

Remarks. In the mode of branching this form must be included in KüKENTHAL'S rigida-group, within which it does not agree with any known species.

\section{UMBTLLATAE}

\section{Dendronephthya dromidicola $\mathrm{n} . \mathrm{sp}$.}

(Fig. 17; Plate X, Fig. 15)

A very large, flaccid colony covering upon the back of the dromiid crab, Dromidiopsis dromia (LinNe), having a height of about $10 \mathrm{~cm}$ (when alive, attaining to $15 \mathrm{~cm}$ in an expanded condition) and a polyparium expanse of 
$19 \times 18 \mathrm{~cm}$. Another specimen showing the same habit has a polyparium expanse of $12 \times 5 \mathrm{~cm}$.

Basal attachment very broad, flattened with a maximum diameter of $11 \mathrm{~cm}$, and entirely bare. It gives rise on upper surface to six very plump main branches of approximately the same length, which in turn divide into terminal short twigs where the polyps are located. Terminal twigs in form of umbels grouped together to form hemispherical clusters, alj umbels being formed superficially on outer surface of polyparium. Lowest branches, surrounding the base are all short and slightly foliaceous, but located at a height of about $1 \mathrm{~cm}$ only from the base, so that ordinary stalk portion may not be delimited from the basal disc proper, nor from the polyparium.

At each end of terminal twigs, about $1.5-1.8 \mathrm{~mm}$ in diameter, usually 5 or 6 polyp groups are located. In each group, 5 to 10 polyps are closely massed and share, a single supporting bundle. Therefore, a largest terminal polyp only bears it, while the other additional smailer ones have none. In many cases, a twig bears only a prominently developed S.B. (composed of about 5 strong spindles) and several less-developed S.B. (composed of 1-3 smaller spicules); in the former case, spicules composing the bundle are as long as $8.5 \mathrm{~mm}$ and may project for about $3-4 \mathrm{~mm}$ long beyond polyp head terminally located, while in the latter they are shorter than $2 \mathrm{~mm}$ and do not project beyond polyp head. In every case. main polyps may stand almost upright, extending parallel to S.B.

Polyp head rounded, rather small, about $0.28-0.4 \mathrm{~mm}$ long and $0.4-0.52 \mathrm{~mm}$ wide. Polyp stalk very plump, a little narrower than head, and rather short, though varying in size. Anthocodial armature very characteristic, showing the most primitive feature belonging to Grade I. Anthocodial spicules are very numerous, small, densely packed rods in eight converging points, mostly not forming any regular double rows; usually those of upper and inner parts are yellow or yellowish white, while those of basal and outer parts brownish red in color. Largest polyp spicule is about $0.07 \mathrm{~mm}$ long and $0.017 \mathrm{~mm}$ wide, although many are much smaller. In tentacles also are numerous tiny, similar spicules arranged transversely, usually yellowish white, but often merged with reddish ones as in polyp heads, measuring about $0.014-0.028 \mathrm{~mm}$ long and 0.005 $\mathrm{mm}$ wide. Below polyp head also numerous brownish red-colored tiny rods are sparsely set on all surface of cortex from polyp stalk down to terminal branches; they are of ten arranged in eight longitudinal rows on polyp stalk only, but become more irregular and sparse downwards; about $0.07 \times 0.008 \mathrm{~mm}$, $0.05 \times 0.017 \mathrm{~mm}, 0.14 \times 0.026 \mathrm{~mm}$. S.B. spicules are all slender spindles covered with close-set minute low warts all over and always orange-colored, deepest 
at middle. Anthocodial formula :

$I=$ many $p+0 \mathrm{Cr}+$ very strong S.B.

In cortex of branches, there are also slender spindles similar to those of S.B., about $2-7 \mathrm{~mm}$ long, though much more sparse than tiny rods. They are longitudinally disposed and orange-colored in upper branches, but become downwards much more sparse and paler to yellowish in color. Basal cortex free from spicules, except for around the lowest branches. Canal-walls relatively thick, fleshy in texture and also devoid of spicules.

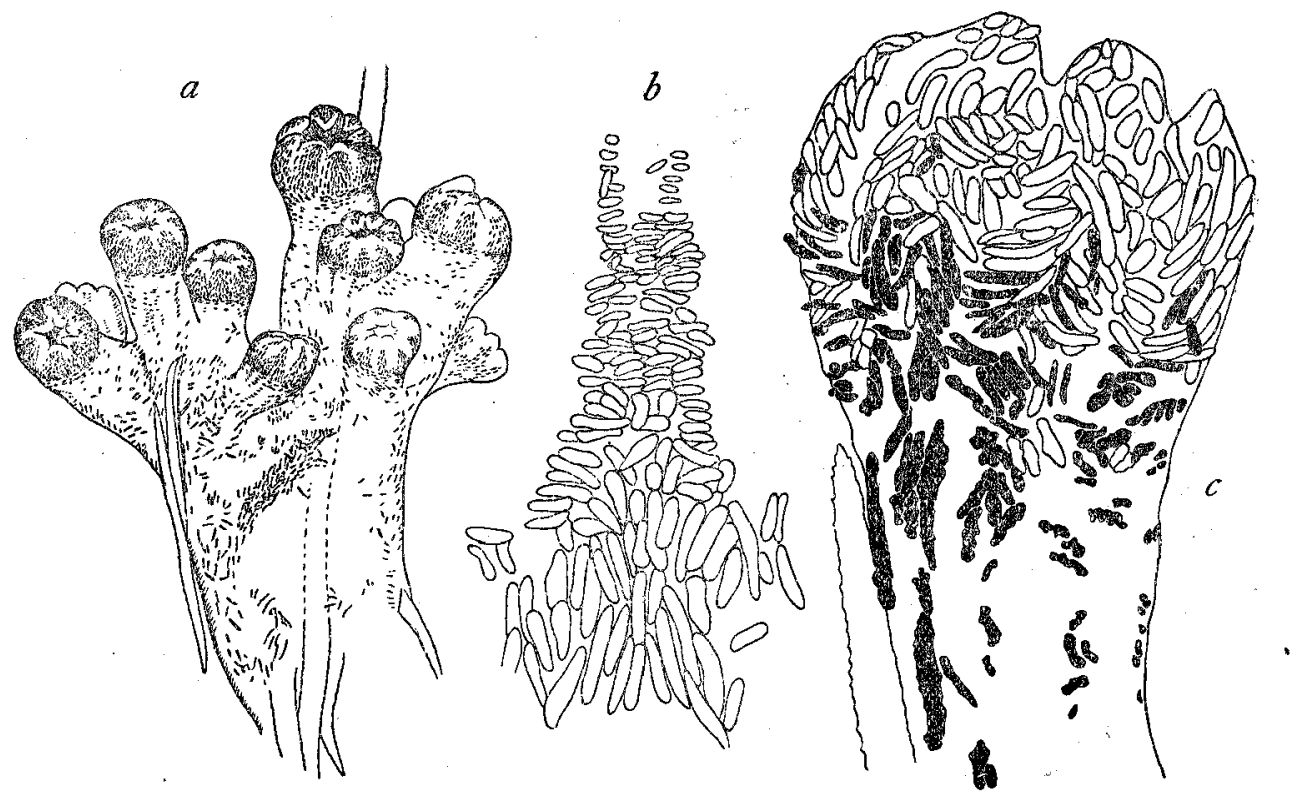

Fig. 17. Dindronephthya dromidicala n. sp. a, Terminai twig bearing a nut ier of polyps supported by a single bundle of spicules; $b$, arrangement of tentacle spicules continued insensibly into point spicules; $c$ terminal polyp, showing the arrangement of red-colored (black outlined) and yellow colored (white outlined) spicules, $\{a \times 18, c \times 80, b \times 150\rangle$

Coloring. On the whole terminal twigs and polyps reddish-orange, branches and basal cortex yellowish-white.

Localiy. (Holotype) Tanabe Bay, $5 \mathrm{~m}$. Nov. 23, 1951; (Paratype) Tanabe Bay. April 19, 1952. T. Yамамото leg.

Remarks. In polyp spiculation this interesting form comes nearest to D. repens of KUKENTHAL's rubra group and also to $D$. villosa of dendrophytagroup, both belonging to the Umbellatae division. Yet the general mode of branching may conform with the type of collaris group. In general branching and spiculation, the present form seems to be allied to Spongodes capitata from Hongkong, which was described by VkRRILL (1864, p. 40; 1865, p. 193) 
very briefly without any figure and later treated by KükENTHAL (1905, p. 708) only as 'Species incertae sedis' of Dendronephihya. However, it is now very doubtful if both are the same species. To solve this question, re-examination of VERRILL's type specimens, if still present, is much desirable. Therefore, I herewith tentatively describe the present form as a new species belonging to the Umbellatae group.

The chief interest lies, however, in the following peculiarities:

(1) Cortical spicules consists of two types only, rod and spindle. No specialized spicule exists.

(2) Rodlike spicules are very tiny, numerous and almost similar to one another in every portion of tentacles, polyps and branches.

(3) S.B. spicules and cortical spicules of spindle form are similar in structure and insensibly connected together.

(4) A number of polyps at ends of twigs are supported only by a common bundle of spicules located on the dorsal side of parent polyp stalk.

(5) Weak spiculation of cortex and no spiculation of canal-walls, together with the thickness of canal-walls, are very distinctive.

These outstanding features may speak for this form to be the most primitive form of this group, having an affinity with the Alcyoniidae. The habit is also remarkable and very peculiar for this group. It is hard at present to tell whether this lodgment on the back of the dromiid crab is natural or commensal, or else only accidental. However, it may not be an unusual example, since I have ever obtained here another kind of the crab, Dromidia unidentata, carrying an Alcyonium-like colony on the back. In the recesses of the polyparium there lay a number of a commensal polynoid, Scalisetosus levis MARENZELLER, and a pair of a white-colored snapping shrimp, Synalpheus sp., as in other examples of Dendronephihya.

\section{Dendronephthya spimulosa (GRAY)}

(Fig, 18; Plate X, Fig. 14)

Morchellana spinulosa, GRAY $(1862$, p. 30; 1869, p. 130).

S pongodes spinulosa, RIDLEY (1882, p. 186;.

Dendronephthya spinulosit, KÜUENTHAL (1905, p. 681).

A large, flexible, long-stalked colony with umbellate polyparium; its total height is about $30 \mathrm{~cm}$ of which $22 \mathrm{~cm}$ belongs to the stalk. Stalk flexible, apparently leathery in texture, cylindrical, gradually narrower upwards and at 
its base furnished with some large tubular stolons entangled with sand and shell particles; its lower half is thickly covered with colonies of a bryozoan, Barentia discreta. Polyparium distinctly flattened in one plane and formed of an erect main stem and five long, cylindrical side branches of different lengths; these branches are widely apart so that the outline of polyparium is irregular. In addition, at the base of polyparium there are two broad foliate branches, turned downwards, below which the stem is somewhat constricted.

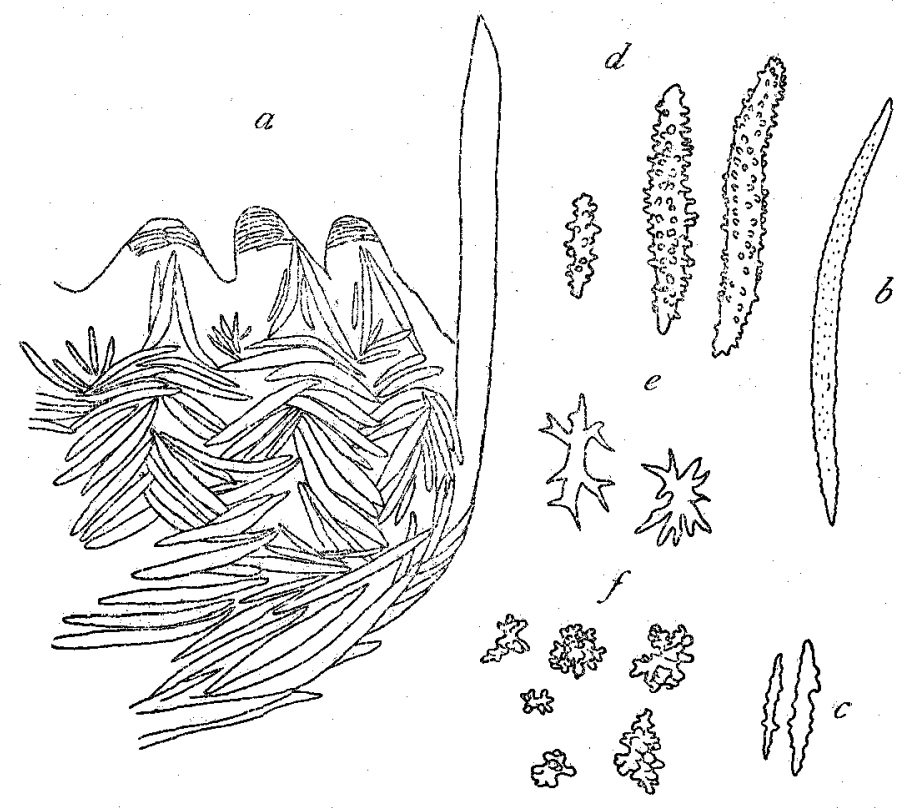

Fig. 18. Dendroneplithya spinulosa (GRAY). a, Polyp; $b$, spindle from poiyp stalk; $c$, tentacle spicules; $d$, spindles from upper cortex; $e$, antler-iike flat bodies from canal-walls of branches; $f$, stellate spicules from stalk cortex. $\left\{b, d, f \times 55, a \times 70, c_{2} e \times 150\right\}$

Polyp groups occurring on terminal twigs are almost collapsed and brittle. Polyp head very small, about $0.4 \mathrm{~mm}$ long and as many wide; standing at an obtuse or almost right angle with very short polyp stalk. Anthocodial armature in eight double rows, 10-12 in a row. Uppermost one or two pairs a little longer and longitudinally disposed, below these 8-10 converging pairs closely disposed. All these spicules are weakly warted spindles of subequal length, about $0.13-0.17 \mathrm{~mm}$ long in transverse rows. Two pairs of small intermediate spicules are usually found between uppermost points. Tentacle spicules white or reddish, elongate, toothed flat rods with sharp ends, about $0.07 \mathrm{~mm}$ long at base. S.B. of the entheathing type, as in $D$. annectens SHERRIFs, and very inconspicuous, but in polyps occurring on lowest foliaceous branches 1 to 
3 spicules somewhat prominent and slightly project out of polyp head. Anthocodial formula:

$$
\mathrm{II}=(10-12) \mathrm{p}+0 \mathrm{Cr}+\text { very weak S.B. }+2 \mathrm{M}
$$

Very noteworthy is the spiculation of cortex: In cortex of stem and branches are thickly warted spindles up to $2.5 \mathrm{~mm}$ long and $0.23 \mathrm{~mm}$ wide, but mostly smaller spindles, from $0.17 \times 0.03 \mathrm{~mm}$ to $1.1 \times 0.1 \mathrm{~mm}$. In cortex of stalk are densely disposed small capstan-like or star-shaped almost globular warty spicules, about $0.07-0.14 \mathrm{~mm}$ across. In canal-walls of twigs, there are antlerlike flat discs, about $0.065-0.075 \mathrm{~mm}$ long in abundance, but those become fewer downwards in branches and main stem; in stalk these antlers are not found at all.

Coloring. Polyp spicules purplish-red, other cortex reddish, paler upwards and darker downwards, leading to brick or brownish red towards the basal portion of stalk.

Locality. Tanabe Bay, $20 \mathrm{~m}$.

Previously recorded from Indian Ocean and China Sea.

Remarks. In general coloration and anthocodial architecture, this specimen resembles closely $D$. spinulosa described and figured by KüKENTHAL (1905), except as regards the details of spiculation. The outstanding disagreements may be the following three points:

(1) The number of point spicules in a row is more numerous.

(2) The tentacle spicules are elongate, instead of being short and broad.

(3) In canal-walls, spindles or allied spicules are not found.

KÜKENTHAL, however, recognizes that there is considerable variability in this species. His examined specimens may be rather younger forms, being, according to him, $13.5 \mathrm{~cm}$ and $5.3 \mathrm{~cm}$ in total height. If my identification is correct, I like to suppose these differences as variations dependant on growth. I agree, on the other hand, with KüKENTHAL as to the assignment of this species to the Umbellate group, as the terminal twigs compose large hemispherical umbels.

\section{Dendronephthya pellucida n. sp.}

(Fig. 19; Plate X, Fig. 16)

A gigantic colony of umbellate branchings, about $35 \mathrm{~cm}$ in total height and $25 \mathrm{~cm}$ in maximum expanse. It has a very plump and flaccid trunk, about $12 \mathrm{~cm}$ in maximum diameter, and at the base bears numerous long stolons entangled with debris and sands. 

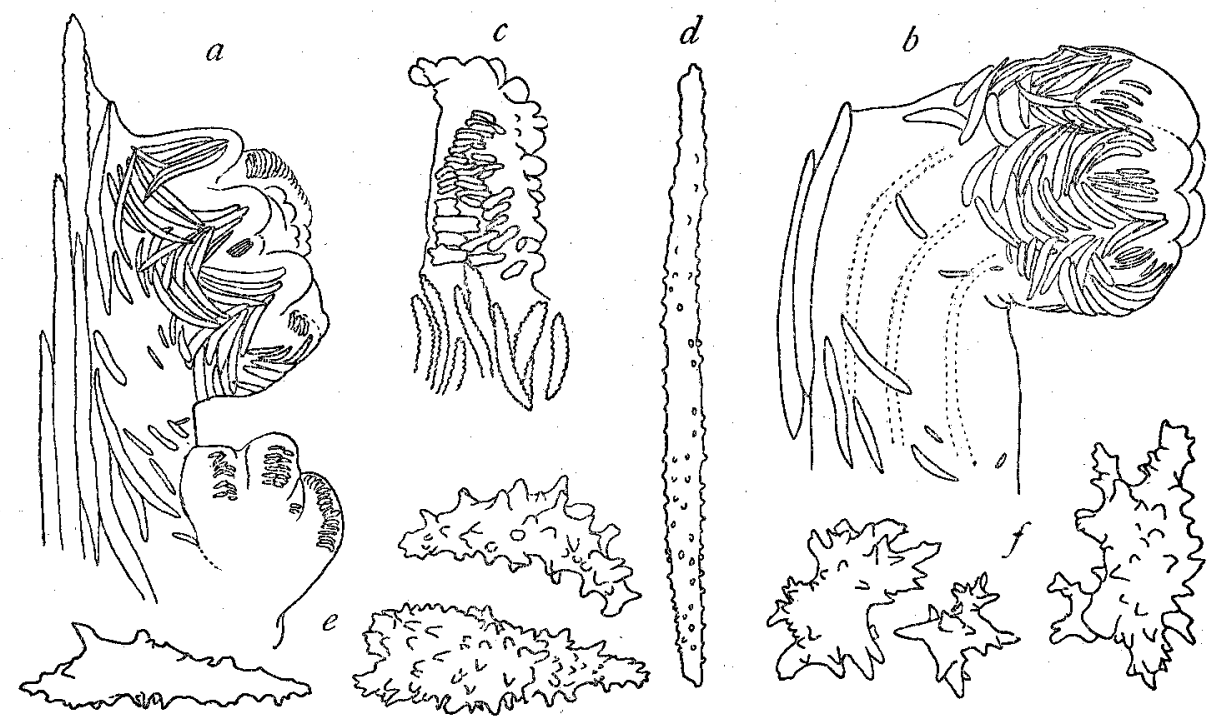

$F_{1 g}$. 19. Dendronephthya pillucida n. sp. $a, b$, Polyp; $c$, arrangement of spicules in tentacle; $d$, spindle from cortex of twigs; $e$, spicules from cortex of basal stalk; $f$, large spicules from canal-walls. $(a, b \times 50, c-f \times 70\}$

For the first $3 \mathrm{~cm}$ in height the stem is bare; then there arise a series of small foliate branches (about 50 in number) around the stem, and then at a height of $8 \mathrm{~cm}$ and $12 \mathrm{~cm}$ from the base, strong main branches, about $5-6 \mathrm{~cm}$ broad, are borne. A little higher up, two large branches are given off and then the main stem forks terminally. The polyparium is formed by further ramification of these main branches; thus the outline of polyparium is not uniform and not flattened laterally, but the umbe's of terminal twigs form each a large hemispherical upper surface.

Polyps compactly massed in groups of 10-20 at top of short-stalked terminal twigs located on surface of the colony. Polyp head, about $0.5 \mathrm{~mm}$ long and $0.7 \mathrm{~mm}$ wide, round cup like, making a right or slightly obtuse angle with a short plump stalk. Anthocodial armature consists of 6-8 pairs of spindles of subequal length, about $0.26-0.33 \mathrm{~mm}$ long, which fit closely together in eight points. Between points usually occur 2 or 3 pairs of smaller intermediate spicules. Tentacles long, with elongate or oval rodlike red spicules, about $0.046-0.056 \mathrm{~mm}$ long, in bilinear rows. S. B. consists of 3-5 very weak, less-spinose spicules, usually not projecting beyond polyp head; in certain cases one may be as long as $1.3 \mathrm{~mm}$ and slightly project. Polyp stalk, usually shorter than $1 \mathrm{~mm}$ and $0.4-0.6 \mathrm{~mm}$ wide, very plump, pellucid and almost nude. Anthocodial formula: 


$$
\mathrm{II}=(6-8) \mathrm{p}+0 \mathrm{Cr}+\mathrm{weak} \text { S.B. }+(2-3) \mathrm{M}
$$

Cortex of terminal twigs covered very sparingly with slender, red or brick-red, spindles with sparsely-set low warts, up to $1 \mathrm{~mm}$ long, which become larger on smaller branches up to $3 \mathrm{~mm}$ long. Cortex of larger branches and main stem are, however, wholly nude. In short basal stalk. there are many of red or white, cortical spicules, consisting of dumb-bells, pseudo-clubs and star-shaped forms covered with strong thorns, about $0.1-0.4 \mathrm{~mm}$ long. In canalwalls also many smaller, colorless, translucent, flat rodlets with bi- or trifurcate ends, about $0.09-0.14 \mathrm{~mm}$ long and $0.001 \mathrm{~mm}$ wide occur. There are also larger, very thorny spindles and derivatives, though relatively few in number; $0.35 \times 0.12 \mathrm{~mm}, 0.37 \times 0.14 \mathrm{~mm}, 0.5 \times 0.2 \mathrm{~mm}$.

Coloring. Polyp armature and twigs brick-red in upper part of the colony, while dark red in lower branches. Polyps themselves yellowish. Cortex of main stem and branches brownish yellow, while stalk cortex blood-red.

Lacality. Tanabe Bay, $15 \mathrm{~m}$.

Remarks. In the mode of branching and the anthocodial armature this specimen comes very near to $D$. dendrophyta (WRIGHT \& STUDER) recorded from China Sea and Philippines, but the spiculation of the cortex and canalwalls and also its gigantic size are so different and distinctive that $I$ am compelled to establish a new species.

\section{Dendronephthya habereri $\mathrm{K} U ̈ \mathrm{KENTHAL}$}

(Fig. 20; Plate X, Fig. 17)

Dendronephthya habereri, KüKENTHAL (1905, p. 638), THOMSON \& DEAN (1931, p. 121 ).

A compact and very stiff colony of the Umbellate type. Polyparium considerably flattened in a long oval contour; in one specimen, it is about $6.4 \mathrm{~cm}$ high, $9 \mathrm{~cm}$ wide and $3.5 \mathrm{~cm}$ in thickness. Stalk very short, completely hidden under lowest foliaceous branches of polyparium. Base broadly flattened, encrusting rock or stones.

Polyp head small, rounded, about $0.4-0.5 \mathrm{~mm}$ long and $0.6-0.8 \mathrm{~mm}$ wide, standing at a right angle with short poiyp stalk, up to $0.8 \mathrm{~mm}$ long. Uppermost points somewhat larger, a little projecting, but usually incurved over the mouth. Tentacles and spaces between points heavily armoured with tiny rodlike spicules. Anthocodial formula:

$\mathrm{III}=(5-6) \mathrm{p}+0 \mathrm{Cr}+$ strong S.B. + many $\mathrm{M}$

Cortex of branches and upper part of stalk thickly covered with very 


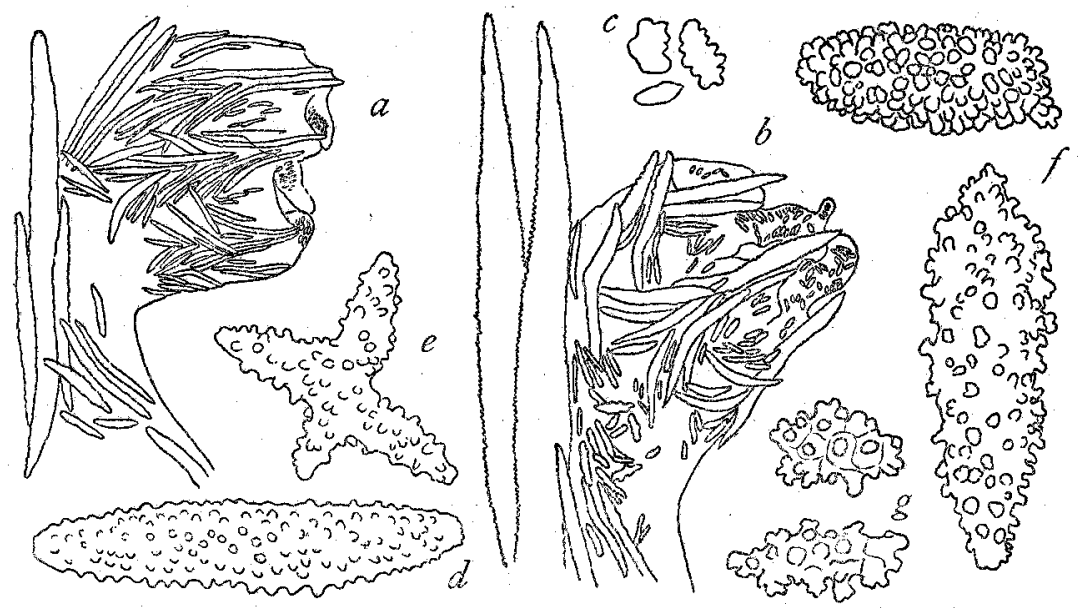

Fig. 20. Dindronephthya habereri KÜKTH. $a, b$, Polyp; $c$, tentacle spicules; $d$, spindie from upper cortex; $e$, quadriradiate form from basal cortex; $f, g$, spicules from canai-walls. $(a, b, d, e \times 35, f, g \times 55, c \times 150)$

large, plump, strongly warted spindles up to $3.5 \mathrm{~mm}$ long and $0.35 \mathrm{~mm}$ wide, usually bluntly ended. On basal flattened part of stalk are shorter, very plump spindles, triradiates, quadriradiates with strong rounded warts, up to $1 \mathrm{~mm}$ long and $0.18 \mathrm{~mm}$ wide. Canal walls thickly filled with similar spicules.

Coloring. All spicules of polyps and branches purple-red, stem bright red to white, while basal expanded portion of stalk dark or bright red.

Localities. Tanabe Bay and Kusimoto. Common.

Remarks. As KüKenthal and Thomson \& DEAN point out, there is considerable variability in this species. Another specimen, which is $10 \mathrm{~cm}$ high, $7.5 \mathrm{~cm}$ wide and $4.2 \mathrm{~cm}$ thick, shows the same anthocodial armature, but it differs in coloration of polyps and in spiculation of lower cortex. In this, the polyps and their spicules are yellow, while the spicules of S. B. and polyp stalk are chocolate red. The spicules of lower cortex are all much more robust, bluntly ended, warty spindles, up to $3.5 \mathrm{~mm}$ long and $1 \mathrm{~mm}$ wide, which lead to almost globular very knobby forms, but not multiradiate forms.

\section{Dendronephthya dofleini KüKENTHAL}

(Fig. 21; Plate XI, Fig. 28)

Dendronephthya dofleini, KÜKENTHAL (1905, p. 662), THOMSON \& DEAN (1931, p. 131).

Two small specimens obtained at different stations agree well with this 
species. One complete specimen is $3.2 \mathrm{~cm}$ high, of which about one-half belongs to sterile stalk bearing stolons at base. In another one, the polyparium is almost globular in outline, somewhat flattened laterally, and about $2.8 \mathrm{~cm}$ long and $3 \mathrm{~cm}$ wide, the stalk being missing.

Polyp head, about $0.5 \mathrm{~mm}$ long and $0.6 \mathrm{~mm}$ wide, standing at a right or obtuse angle with short stalk, less than $1 \mathrm{~mm}$ (in foliaceous branches, however, up to $2 \mathrm{~mm}$ long). Anthocodial formula :
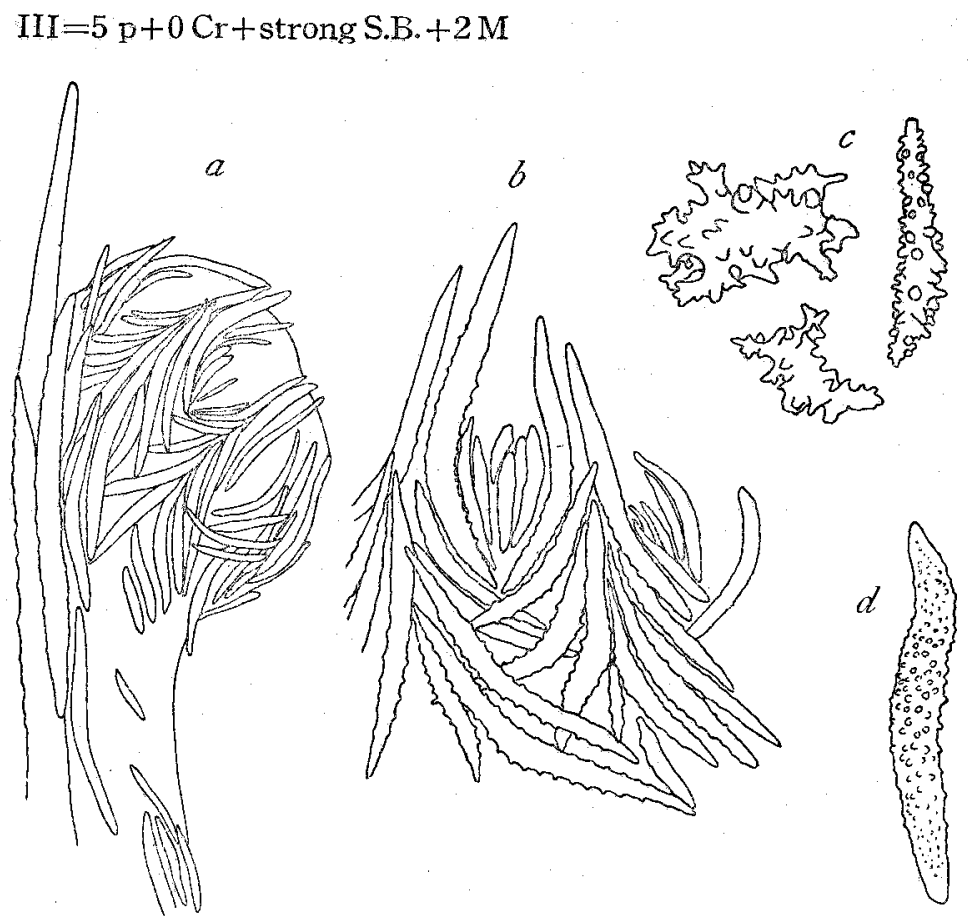

Fig. 21. Dendronephthya dofleini KÜKTH. a, Polyp; $b$, part of anthocodial armature; $c$, spicules from lower cortex; $d$, spindle from canalwalls. $(d \times 35, a, c \times 55, b \times 65)$

On upper cortex are long curved spindles up to $2.5 \mathrm{~mm}$ long; in foliaceous: branches, however, they attain a length of about $5 \mathrm{~mm}$. On lower cortex are short spindles with rounded warts about $0.35 \times 0.07 \mathrm{~mm}$, mingled with many strong warty triradiates, quadriradiates and stellate forms, mostly about $0.35 \mathrm{~mm}$ across. Canal walls rather thick and sparsely filled with warty spindles with almost smooth ends, about 1-1.5 mm long.

Coloring. Wholly yellowish white or glossy white, but examination with a lens reveals that a few red colored spicules are mingled in some places, though not so confined to polyps as shown in previous descriptions.

Localities. Seto and off Minabe, $100-200 \mathrm{~m}$.

Previously recorded from Hongkong, Malay Peninsula and Kei Islands. 


\section{Dendronephthya pulchella $\mathrm{n}$. sp.}

(Fig. 22; Plate XI, Fig. 30)

A small beautiful colony with loosely disposed umbels. Polyparium consisting of 2 main branches somewhat flattened in an elongate-oval contour, about $4 \mathrm{~cm}$ long and $3.2 \mathrm{~cm}$ wide. Stalk slender, limp, about $2 \mathrm{~cm}$ long and $8 \mathrm{~mm}$ wide at its mutilated base. Surface of polyparium practically even, covered with umbels of approximately the same length (about $4-5 \mathrm{~mm}$ ); heads of lower umbels with radially shooting groups of polyps are slightly flattened making a narrow flat disc, but not forming any ordinary foliaceous collar around stem.

Polyps in divergent groups of $2-5$ at top or margins of umbels. Polyp head cuplike, about $0.58-0.65 \mathrm{~mm}$ high and $0.76 \mathrm{~mm}$ wide, making almost a right angle with slender stalk up to $1 \mathrm{~mm}$ long and $0.4 \mathrm{~mm}$ wide at base. Anthocodial armature in eight double. rows of almost smooth, slender spicules, 5-7 in a row. Outermost pair markedly longer, about $0.26-0.5 \mathrm{~mm}$ long, a little projecting beyond head and almost twice as long as lower ones $(0.12-0.26 \mathrm{~mm}$ long). A few intermediate spicules occur between points. Tentacles with 2

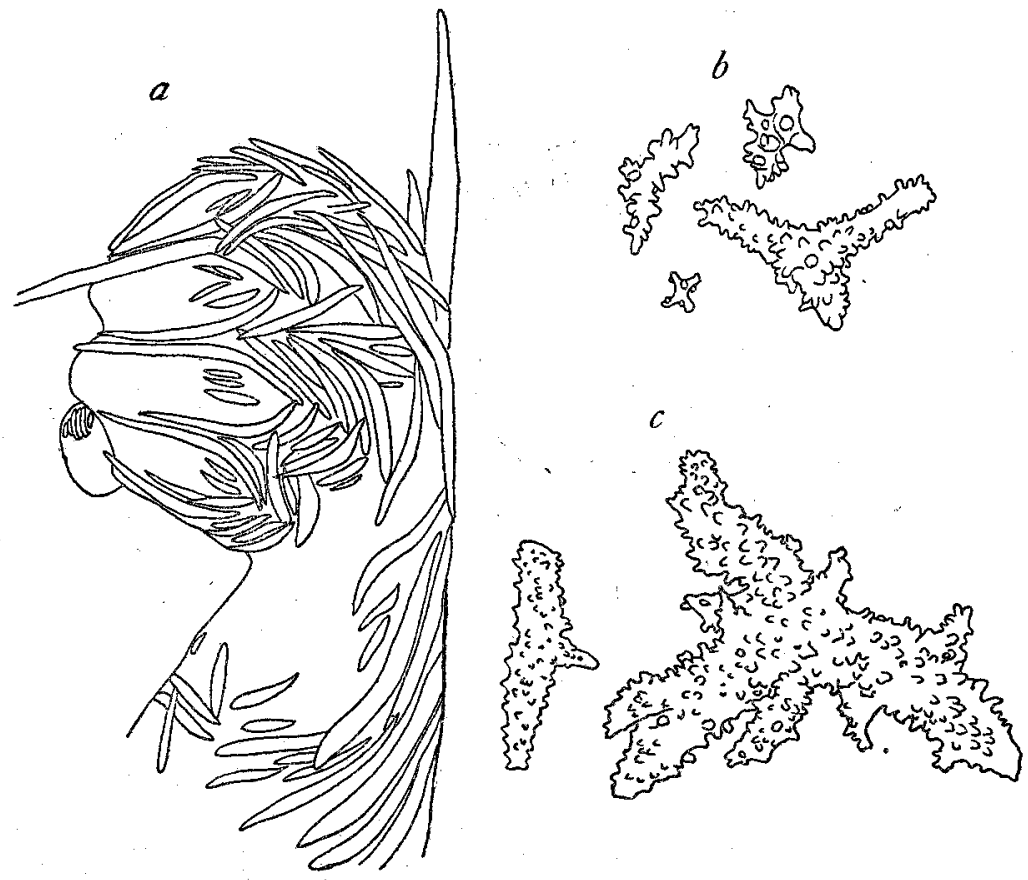

Fig. 22. Dendronephthya pulchella n. sp. $a$, Polyp; $b$, spicules from lower cortex; $c$, spicules from canal walls of stalk. $(c \times 35, a, b \times 55)$ 
distinct rows of transparent, flat rods, about $0.028-0.047 \mathrm{~mm}$ long, densely disposed transversely. S. B. fairly developed and usually only one spicule projects freely for up to $1 \mathrm{~mm}$ long; all are finely warted with a smooth projecting tip and about as long as $3 \mathrm{~mm}$. Anthocodial formula:

$$
\text { III }=1 \mathrm{P}+(4-6) \mathrm{p}+0 \mathrm{Cr}+\text { strong S.B. }+(1-2) \mathrm{M}
$$

Upper cortex covered with pinkish white slender spindles, up to $3 \mathrm{~mm}$ long, arranged longitudinally. On lower cortex are numerous, smaller, pink or white, curved warty spindles, triradiates, multiradiates and stellate forms, about $0.09-0.3 \mathrm{~mm}$ long, together with larger curved spindles up to $0.88 \mathrm{~mm}$ long and $0.1 \mathrm{~mm}$ wide, occurring sparingly. Canal-walls of upper branches free from spicules, but those of stalk filled with large, pink or white, plump spindles, triradiates and multiradiates with prominent warts, measuring $0.88 \times 0.23 \mathrm{~mm}$, $1.76 \times 0.24 \mathrm{~mm}$.

Coloring. Polyps and their spicules ivory white, S.B. and twigs pink, stalk and branches pinkish white.

Locality. Tanabe Bay, $10 \mathrm{~m}$.

Remarks. The umbellate branching of polyparium in no very uniform outline points to KüKENTHAL's spinulosa group. In general appearance it comes near to $D$. hyalina known from Pescadores and Malayan waters, but differs distinctiy in many respects, especially as regards the anthocodial and cortical spiculation and the coloration.

\section{Dendronephthya disciformis KÜKENTHAL}

(Fig. 23; Plate X, Fig. 18)

Dendronephthya disciformis, KÜKENTHAL (1905, p. 636), SHANN (1912, p. 519), THOMSON \& DEAN (1931, p. 136).

A compact, disc-like, umbellate colony with very short stalk, about $5.5 \mathrm{~cm}$ long, $7 \mathrm{~cm}$ wide and $3.3 \mathrm{~cm}$ thick. Polyparium composed of a large number of shortly divergent, plump branches of which terminal umbels are superficially in close contact, forming a uniform outline, but laterally flattened. Lowest two large side branches and two small median branches form a complete collar around the base of stem and completely hide the stalk, so that it is only visible from undersides.

Polyps in compact groups of 4-20. Polyp head about $0.5 \mathrm{~mm}$ long and $0.65 \mathrm{~mm}$ wide, making an obtuse angle with polyp stalk not over $1 \mathrm{~mm}$ long. Anthocodial armature very irregular and variable, but usually consists of eight double rows, a strongly projecting uppermost one and $3-4$ obliquely or 
almost transversely arranged spindles in each row. In addition there are usually 2 pairs of small intermediate spicules between uppermost points. Tentacle spicules sparse, colorless, about $0.1 \mathrm{~mm}$ long. S. B. strongly developed, largest spicules as long as $3 \mathrm{~mm}$ projecting for up to $1 \mathrm{~mm}$ long beyond polyp head, with a smooth free tip. Anthocodial formula:

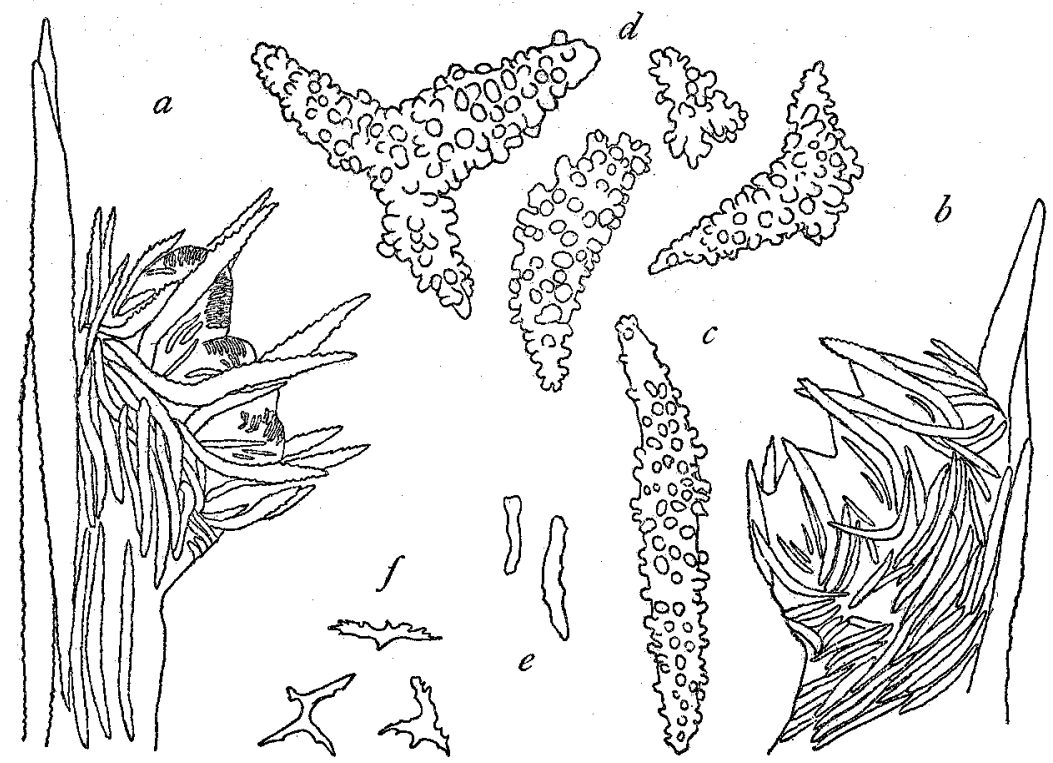

Fig. 23. Dndronephthya disciformis KüKTH. $a, b$, Polyp; $c$, spindle from upper cortex; $d$, spicules from basal cortex; $e$, tentacle spicules; $f$, antler-like bodies from canal-walls. $(a \rightarrow c \times 35, d, f \times 55, e \times 130\}$.

$$
I V=1 \mathrm{P}+(3-4) \mathrm{p}+0 \mathrm{Cr}+\text { very strong S.B. }+2 \mathrm{M}
$$

Cortex of branches and twigs densely covered with pink to reddish white, warty spindles up to $3 \mathrm{~mm}$ long and $0.18 \mathrm{~mm}$ wide; they are arranged longitudinally in terminal branches and twigs, while transversely in main branches and stem. On basal cortex are mostly shorter curved spindles, triradiates, quadriradiates and stellate spicules with prominent rounded warts, mostly 0.05 $0.7 \mathrm{~mm}$ long. Canal-walls contain numerous spindle like or antler-like toothed flat bodies, about $0.07-0.2 \mathrm{~mm}$ long.

Coloring. Spicules of polyps, S. B. and terminal twigs dark red, branch cortex pink to reddish white, stalk greyish brown. Polyps themselves yellowish brown and tentacles white.

Locality. Tanabe Bay, $5 \mathrm{~m}$. Very common.

Previously recorded from China Sea. Singapore and Malay Archipelago. Remarks. Besides there are in my collection many specimens, washed 
up on beaches or obtained by Jobster-nets from adjacent localities, which I would refer to this species. They are generally more dark red in umbels and below these brilliant orange on cortex of twigs, then paler downwards to white cortex of branches and stem. They are all markedly flattened in one plane, and the spiculation generally corresponds with the preceding.

In a specimen, about $7.5 \mathrm{~cm}$ high and $8 \mathrm{~cm}$ wide, the lower point spicules are sometimes transversely arranged, giving somewhat of an impression of a vague 'pseudo-crown'. The tentacles are very long up to $0.5 \mathrm{~mm}$ long and provided with dark red spicules about $0.05-0,1 \mathrm{~mm}$ long in 2 close-set rows. Intermediate spicules are more numerous and $\mathrm{S}$. B. spicules are more strongly developed, and its projecting largest one extends up to $4 \mathrm{~mm}$ long and $0.2 \mathrm{~mm}$ wide and differently colored at tip and base (Fig. 23a).

In another abnormal specimen, the polyparium is decidedly not flattened in one plane, but irregular in outline, showing somewhat the glomerate fashon of branching. And also the coloration of the lowest foliaceous branches differs from that of the upper umbellate branches, the former branches only being yellow ish white in contrast with the surrounding chocolate-red coloration. This abnormal outgrowth, as well as the abnormal mottled coloration, would seem to depend on the condition of attachment. The other characters are, however, identical with those of the typical form of $D$. disciformis.

\section{Dendronephthya densa KÜKENTHAL}

(Fig. 24; Plate X, Fig. 22)

A small fragment without stalk closely resembles $D$. pumilio KÜKENTHAL of spinosa-group, but it may be referable to $D$. densa of the same group in its tentacular spiculation. Polyparium roughly globular, not flattened laterally, about $2.7 \mathrm{~cm}$ long and $3.7 \mathrm{~cm}$ wide, and with red polyps covered on rounded outer surface of branches, clustered together.

Polyp head somewhat flattened laterally, about $0.6 \mathrm{~mm}$ long and $0.8 \mathrm{~mm}$ wide, making an obtuse angle with polyp stalk up to $2 \mathrm{~mm}$ long. Anthocodial armature in eight points of 5-6 steeply converging pairs, of which uppermost pair larger up to $0.7 \mathrm{~mm}$ long and projects far out of head, especially in laterals. 1 or 2 paired short, slender intermediate spicules are found at a triangular wide space between points. Tentacles long, thickly armed with red, elongate rods about $0.07-0.1 \mathrm{~mm}$ long. S. B. consists of some slender, finely warted spindles, of which one or two predominate, up to $4 \mathrm{~mm}$ long, and a 


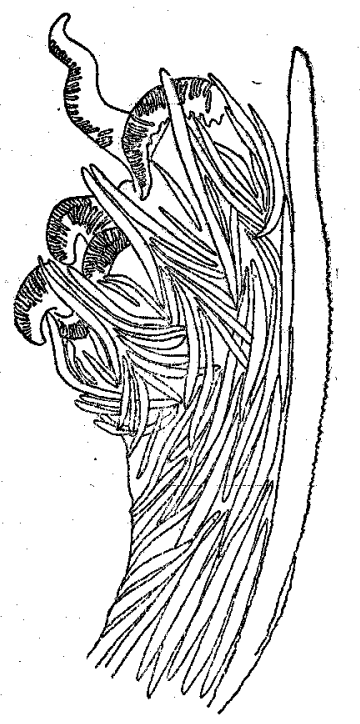

Fig. 24. Dendronepbithya densa KŬKTH. Polyp. $(\times 35)$

little project beyond polyp head. Polyp stalk slender, densely armoured with long spindles lying obliquely. All polyp spicules slender, densely covered with minute warts throughout. Anthocodial formula:

$$
I V=1 \mathrm{P}+(4-5) \mathrm{p}+0 \mathrm{Cr}+\text { medium S.B. }+(1-2) \mathrm{M}
$$

Cortex of branches densely covered with similar spindles up to $2 \mathrm{~mm}$ long. Canal-walls contain only antler like flat bodies up to $0.26 \mathrm{~mm}$ long.

Lo: lity. Off Minabe, $100-200 \mathrm{~m}$. March 1944. S. SAKAGUChI leg.

Previously recorded from Sagami Bay, $150 \mathrm{~m}$.

Remarks. Kükentual (1906, p. 51) describes the tentacle spicules of the type specimen of $D$. densa as colorless. In my specimen, however, it is dis. tinctly redcolored. Such difference in spicular coloration seems to be of no taxonomic importance as shown in examples of the preceding $D$. habereri and $D$. disciformis.

\section{Dendronephihya acaulis KÜKENTHAL}

(Fis. 25; Plate X, Figs. 20, 21)

Dendronephthya acaulis, KüKENTHAL (1906, p. 40), NUTTING (1923, p. 15).

Six small specimens with the same structure, differing from one another in coloration only, can be referred to this species.

Polyparium Stalk Lowest branches Color scheme

A $4.0 \mathrm{~cm} 13.5 \mathrm{~cm} w 2.5 \mathrm{~cm} 11.0 \mathrm{~cm} w$ not foliaceous peach-red

B $4.0,5.0,2.0,1.5$, foliaceous orange

C $3.0,4.0,2.5,1.2, \quad, \quad$, $\quad 4.0$ peach-red

$\mathrm{D} 3.0,3.0,1.0,0.7, \quad, \quad 0 \quad$ pale red

E $3.0,3.0,1.8, \quad 1.0, \quad$ slightly foliaceous yellow

F 2.0 , 2.5 missing not foliaceous "

These specimens may be referred to KüKENTHAL's spinosa-group of the Umbellatae, although KÜrentHal suggests its affinity with $D$. mollis of the Divaricatae. Umbels combined together in form of an almost spherical mass. Stalk cylindrical, about half as long as polyparium and at base with numerous stolons. Lowest branches usually foliaceous. Polyps, about $0.7 \mathrm{~mm}$ long and $0.7-$ 
$0.8 \mathrm{~mm}$ wide, standing at an obtuse angle on slender stalk up to $2 \mathrm{~mm}$ long. Anthocodial armature in eight double rows, 4-5 pairs in a row, of which uppermost pair up to $0.8 \mathrm{~mm}$ long highly projecting beyond polyp head. Inter-

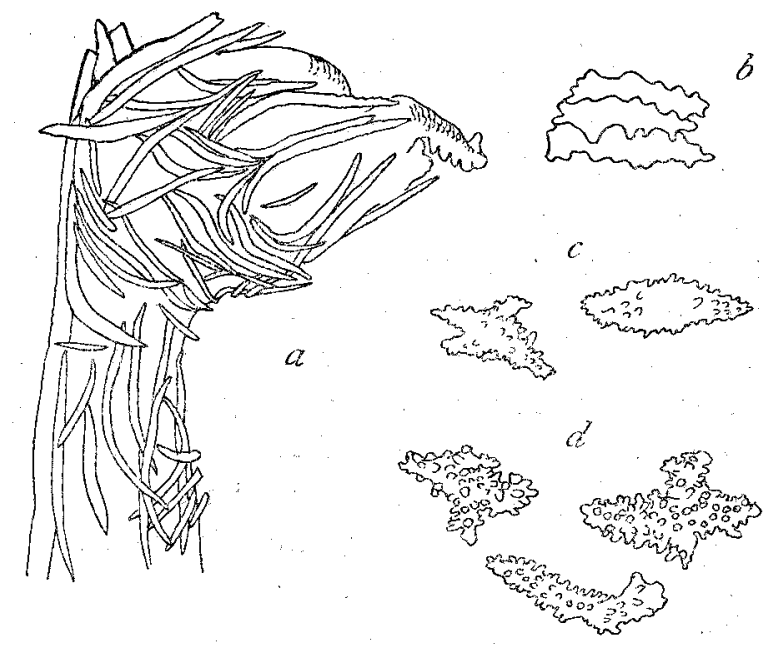

Fig. 25. Dendronephthya acaulis KüKTH. a, Polyp; $b$, tentacle spicules; $c$, spicules from canal-walls; $d$, spicules from lower cortex. $(a, c, d \times 35, b \times 150)$

mediate spicules usually only one, often up to 4 in number. Tentacle spicules colorless, flat rods with jagged edges up to $0.1 \mathrm{~mm}$ long; arranged in 2 rows. S.B. weakly developed, composed of 2 or 3 long spindles up to $3.5 \mathrm{~mm}$ long, mostly shorter, with slightly projecting tip. Ventral side of polyp stalk irregularly disposed with long spindles. Upper cortex with colorless warty spindles up to $2 \mathrm{~mm}$ long. Lower cortex and canal walls with much smaller warty spindles, triradiates and irregular forms, about $0.08-0.4 \mathrm{~mm}$ long. Anthocodial formula :

$$
\text { IV }=1 \mathrm{P}+(3-4) \mathrm{p}+0 \mathrm{Cr}+\text { weak S.B. }+\left(\frac{1}{2}-2\right) \mathrm{M}
$$

Localities. Tanabe Bay, 5-30 m; off Minabe, $100-200 \mathrm{~m}$.

Previously recorded from Japan only (Uraga Strait, $151 \mathrm{~m}$, Ose zaki, $57 \mathrm{fms}$, near Oki Is., $59 \mathrm{fms}$.).

\section{Dendronephthya castanea n. sp.}

(Fig. 26; Plate X, Fig. 19)

Three brilliant colonies of umbellate type taken from different localities were examined. One of them. (Plate X, Fig. 19) taken at Kii-ôsima, which is 
selected as the holotype, is only about $5 \mathrm{~cm}$ in total height, of which one-half belongs to sterile: stalk. Its polyparium very rigid, spiny in appearance, almost circular in outline, and slightly flattened laterally, about $3.5 \mathrm{~cm}$ by $4.5 \mathrm{~cm}$. Lowest branches broadly foliaceous, directed downwards and almost hide the upper half of stalk. Polyps at terminal twigs in form of umbels densely crowded together to form an even outer surface, so that the bare stem and branches are completely hidden. Stalk rather robust, cylindrical and its lower half bearing a few stolons at base is only visible.

A large colony (paratype) from Tanabe Bay shows, however, a different branching type of growth, much like the Glomeratae group. Its polyparium shows an expanse of about $11 \times 9 \mathrm{~cm}$ and a height of about $7 \mathrm{~cm}$. The very short sterile stalk divides into about six main branches, about $4-6 \mathrm{~cm}$ long, which in turn give off numerous secondary branches forming rounded masses of umbels on all sides. Lowest umbels of branches around the sterile stalk are transversely broadened and fairly foliaceous. Thus the growth is rather bushy, so that the contour of polyparium is not uniform. Yet the spiculation and coloration do not differ from the holotype.

Polyps densely massed in groups of 5 to 10 at ends of short robust twigs. Polyp head about $0.53 \mathrm{~mm}$ long and $0.67 \mathrm{~mm}$ wide, more or less compressed laterally, standing at an obtuse angle with slender polyp stalk, about $0.7 \mathrm{~mm}$ long and $0.35 \mathrm{~mm}$ wide at base. Anthocodial armature in eight double rows, 2 to 5 in a row, of which one of the uppermost pair hockey club-like, up to $0.7-0.8 \mathrm{~mm}$ long, extending prominently, and the other shorter, at most $0.3 \mathrm{~mm}$ long. All these spicules covered sparingly with upward-directing thorns and sharply ended. No crown spicules. Between points 1-3 short curved intermediate spicules occur. Tentacles thickly filled with curved, elongate or oblong, small spicules up to $0.1 \mathrm{~mm}$ long and $0.035 \mathrm{~mm}$ wide, not in rows; in a longtime deposited specimen (holotype) the spicule is colorless, while in fresh material from Nada and Tanabe Bay (paratypes) it is chocolate-red in color. S.B. strongly developed, one or two spicules up to $3.5 \mathrm{~mm}$ long projecting for 1-1.5 mm long beyond polyp head; these spicules are densely covered with conical or blunt warts except at the free tip where it is smooth. Ventral side of polyp stalk sparsely armed with slender spindles, mostly $0.45 \mathrm{~mm}$ long. Anthocodial formula:

$$
\text { IV }=1 \mathrm{P}+(1-4) \mathrm{p}+0 \mathrm{Cr}+\text { very strong S.B. }+\left(\frac{1}{2}-1\right) \mathrm{M}
$$

On cortex of stem and branches are strongly warted, yellow or white spindles, about 1-1.5 mm long. On cortex of stalk are yellowish white to colorless, smaller spindles, about $0.7-1.3 \mathrm{~mm}$ long which lead to club-like and irregular-shaped almost globular forms with strong warts. Canal-walls thickly filled with antler-like tiny flat bodies and curved spindles, about $1.3 \times 0.23 \mathrm{~mm}$, 


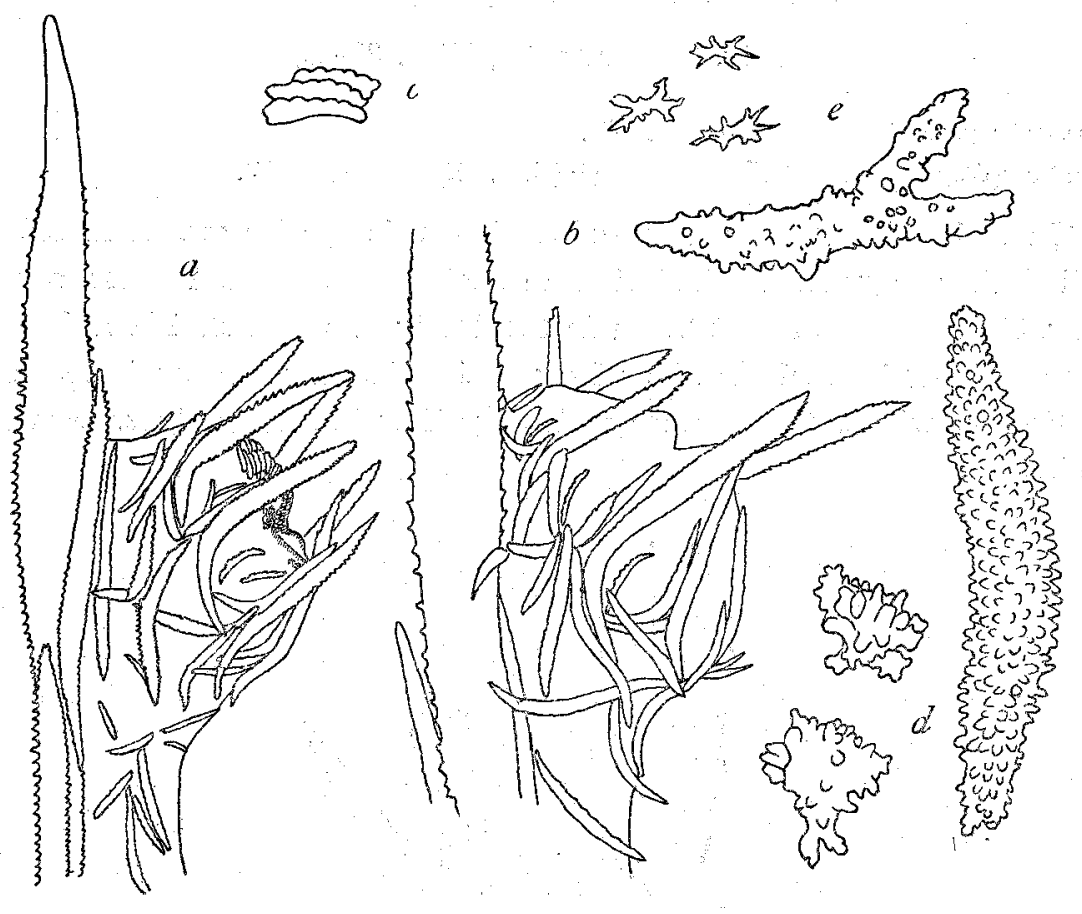

Fig. 26. Dendronephthya castanea n. sp. $a, b$, Poiyp $a$, sp. from Nada; $b$, sp. from Osima); $c$, tentacle spicules; $d$, spicules from lower cortex; $e$, triradiate and antier-iike spicules from canal-walls. (a, $b \times 35, d, e \times 55, c \times 130)$

and triradiates, about $0.7 \times 0.1 \mathrm{~mm}$, are found (in paratype, spindles attain to about $5 \times 0.7 \mathrm{~mm}$ in size).

Coloring. Terminal branches and polyp stalk orange, but polyp head much paler. Point and S. B. spicules glossy white. Stem and stalk dirty yel- lowish or white. Tentacle spicules, when alive, chocolate-red.

Localities. (Holotype) Kii-ôsima. A young specimen. 1944. S. SAKAGUCHI leg. (Paratype) Nada, Hidaka-gun. A fragment. December 12, 1950. T. YAMAMoto leg.; Sisô-zima, Tanabe Bay. A large specimen. Apri] 19, 1952. T. YAMAмото leg.

Remarks. In the uniform grouping of umbels, forming an almost spherical but somewhat flattened polyparium with a short stalk, the type specimen may be referred to KunENTHAL's dendrophyta-group. However, the growth type of the paratype from Tanabe Bay does not agree with it. The polyp spiculation appears like that of D. pecinala (HOLM) and D. mollis (HoLM), both belonging to different groups. It does not, however, agree with any of formerly described species within these groups. 


\section{Dendronephthya pectinata (HoLM)}

(Fig. 27; Plate XI, Figs. 31-33)

Spongodes pectinata, HOLM (1895, p. 47).

Dendrone phthya pectinata, KüKenTHAI. (1905, p. 671; 1906, p. 54).

Three handsome specimens referred to this species are examined. They are all similar in general spiculation and coloration. The largest one (Plate $\mathrm{XI}$, Fig. 33) measures about $24 \mathrm{~cm}$ in total height, of which $14 \mathrm{~cm}$ belongs to the polyparium; its stalk is $10 \mathrm{~cm}$ long and $2-2.5 \mathrm{~cm}$ wide at base. Genera] coloration is white, tinged with whitish yejlow in some polyps. Anthocodial formula :

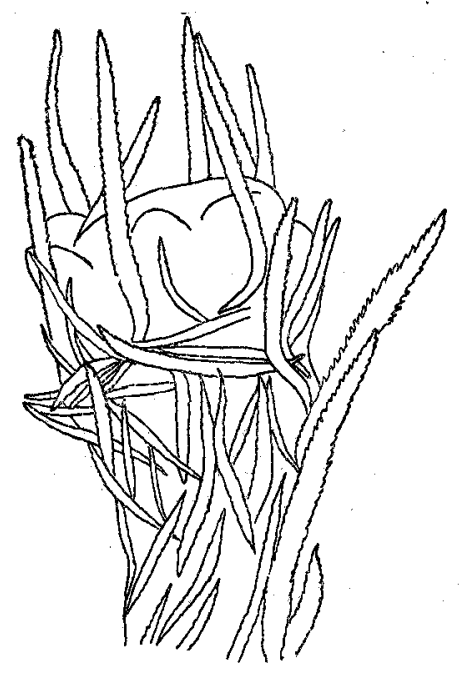

Fig. 27. Dendronephthya poctirata (HOLM). Polyp. \{X35\}

$I V=1 \mathrm{P}+3 \mathrm{p}+0 \mathrm{Cr}+$ medium S.B. $+0 \mathrm{M}$

Canal-walls of upper stem and branches contain, as KüKENTHAL describes, antler-like flat bodies about $0.1 \mathrm{~mm}$ long alone, but those of sterile stalk have none.

Localities. Tanabe Bay, $10-30 \mathrm{~m}$; off Minabe, $100-200 \mathrm{~m}$.

Previously recorded from Japan only (Hirado Strait, Misaki).

\section{Dendronephthya longicaulis KÜKENTHAL}

(Fig. 28; Plate XI, Fig. 34)

Dendroneplithya longicauliw, KÜKKENTHAL (1905, p. 633), THOMSON \& DEAN (1931, p. 141). 
A gigantic colony, about $36 \mathrm{~cm}$ in total height, consists of a very long, flexible stalk ( $27 \mathrm{~cm}$ long) gradually tapering upwards and an irregularly and loosely branched polyparium $(9 \mathrm{~cm}$ long) somewhat flattened. Sterile stalk bears no stolon at base and its whole surface from top to base, oddly enough on one side only, is thickly encrusted with an athecate hydropolyp, Hydrocoryne miurensis STECHOW, as in KüKENTHAL's original type. Two lowest branches of polyparium are foliaceous to form a collar directing downwards. General color of the colony is brownish yellow, though anthocodial spicules are all colorless and transparent.

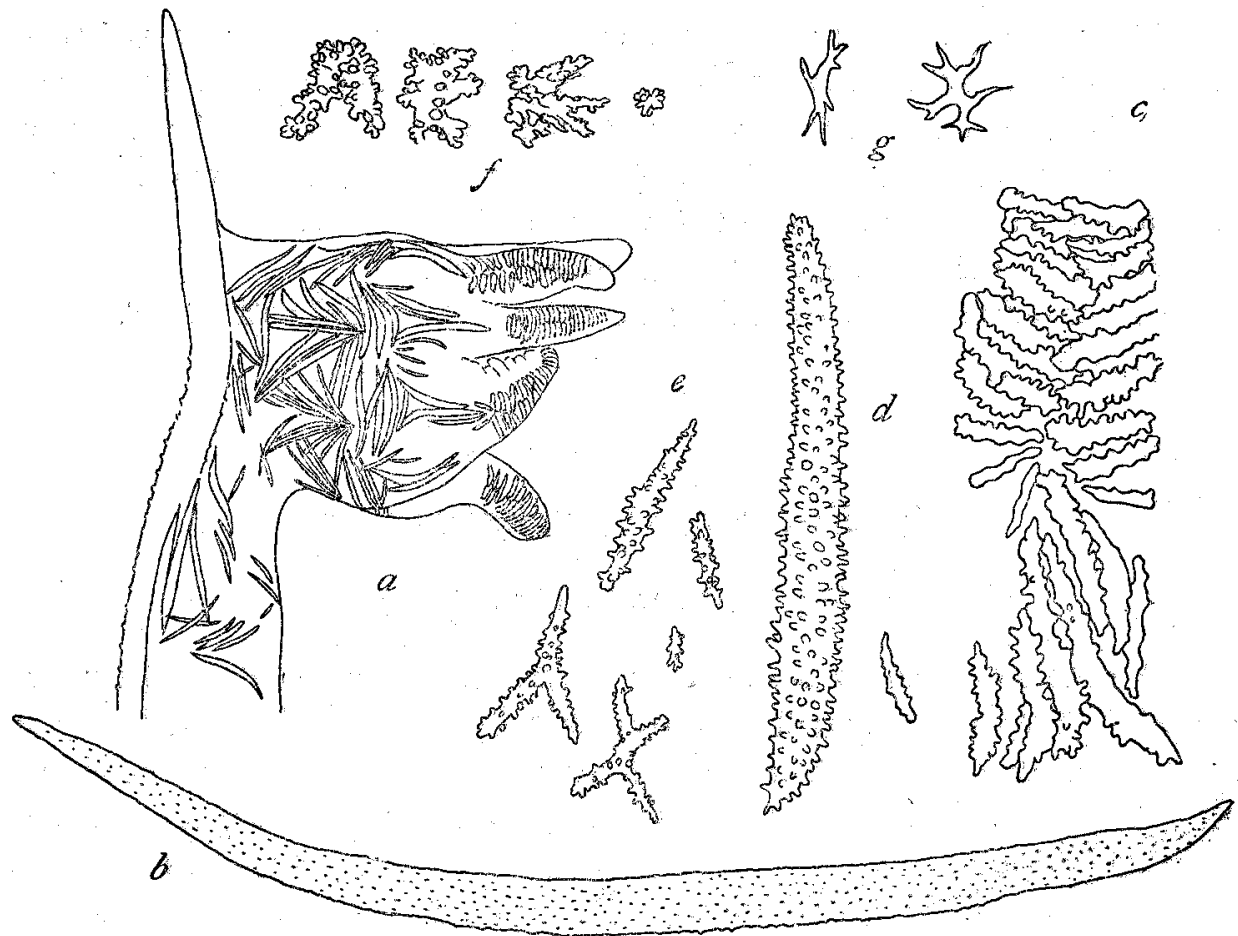

Fig. 28. Dendronephthya longicaulis KÜKTH. $a$, Polyp; $b$, spindle of S. B.; $c$, base of tentacle, showing the arrangement of tentacle and point spicules; $d$, Iarge spindle from upper cortex; $e$, small spindles and derwatives from upper cortex; $f$, stellate spicules from stalk cortex; $g$, antler-like flat bodies from canal-walls of twigs. $(a, b \times 35, d-f \times 50, c, g \times 150)$

Polyp head about $0.7-0.9 \mathrm{~mm}$ long and $0.7-1 \mathrm{~mm}$ wide, standing at a right to obtuse angle with slender, $1 \mathrm{~mm}$ long, stalk. Ventral side of polyp stalk usually almost bare. Anthocodial armature in eight widely spaced points of one pair, below which 2-5 horizontals and 4-10 converging pairs of slender spindles; the number of these crown spicules much exceeds that described by 
former authors. Tentacles with flat rodlike toothed spicules closely set in 2 rows. S. B. weakly developed and scarcely projecting, but often may extend for $0.3-0.8 \mathrm{~mm}$ long beyond polyp head; its spicules up to $3.5 \mathrm{~mm}$ long and very finely warted, though almost smooth toward the ends. Anthocodial formula :

$$
V I=1 \mathrm{P}+(7-15) \mathrm{Cr}+\text { weak S.B. }+(1-3) \mathrm{M}
$$

On cortex of branches and twigs two types of spicules may be found.

(1) Larger spindles; about $0.88 \times 0.08 \mathrm{~mm}, 1.76 \times 0.1 \mathrm{~mm}, 2.2 \times 0.17 \mathrm{~mm}$.

(2) Smaller spindles, triradiates and quadriradiates; about $0.1 \times 0.01 \mathrm{~mm}, 0.3 \times$ $0.015 \mathrm{~mm}, 0.6 \times 0.058 \mathrm{~mm}$.

They are all loosely disposed, somewhat longitudinally in twigs and transversely in main branches. On lower cortex they are all displaced by stellate forms, about $0.1-0.23 \mathrm{~mm}$ long. Canal-walls of twigs and branches contain very sparsely antler-like flat bodies, about $0.07 \mathrm{~mm}$ long, while they are quite absent in stalk, as is also the case with $D$. pectinata.

Locality. Off Minabe, $100-200 \mathrm{~m}$. March 1950.

Previously recorded from Nagasaki, Japan and Sumbawa Island.

\section{Dendronephthya gloriosa $\mathrm{n}$. sp.}

(Fig. 29; Plate X, Figs. 23, 24)

A brilliant orange-colored colony of umbellate type, with a long oval, somewhat flattened polyparium $(8.5 \mathrm{~cm}$ long, $6 \mathrm{~cm}$ wide and $3.4 \mathrm{~cm}$ thick) and a short cylindrical stalk (about $2.5 \mathrm{~cm}$ long and $1.5 \mathrm{~cm}$ wide). A continuous collar formed of two lowest broad foliaceous branches encircling the stem distinctly separates the polyparium from the stalk. Above this the main stem divides into two large branches of unequal. length, which give off loosely on all sides many terminal branches of variable length in form of small umbels. Therefore, the umbels do not combine in larger hemispherical masses. The specimen should therefore be referred to KÜrENTHAL's spinulosa group of the Umbellatae, approaching nearest to $D$. lutea. But the spiculation does not agree with the latter, so as to justify in establishing a new species for this specimen.

Polyps in compact groups of 5-7 at ends of short robust twigs. Polyp head large rounded, about $0.6-0.7 \mathrm{~mm}$ long and $0.8-1 \mathrm{~mm}$ wide, standing at a very obtuse angle with short, plump stalk up to $1 \mathrm{~mm}$ long. Anthocodial armature consists. of eight points, each one with 2 large, stout, hockey-clublike spindles, sometimes appended with a smaller one at base; one of the 


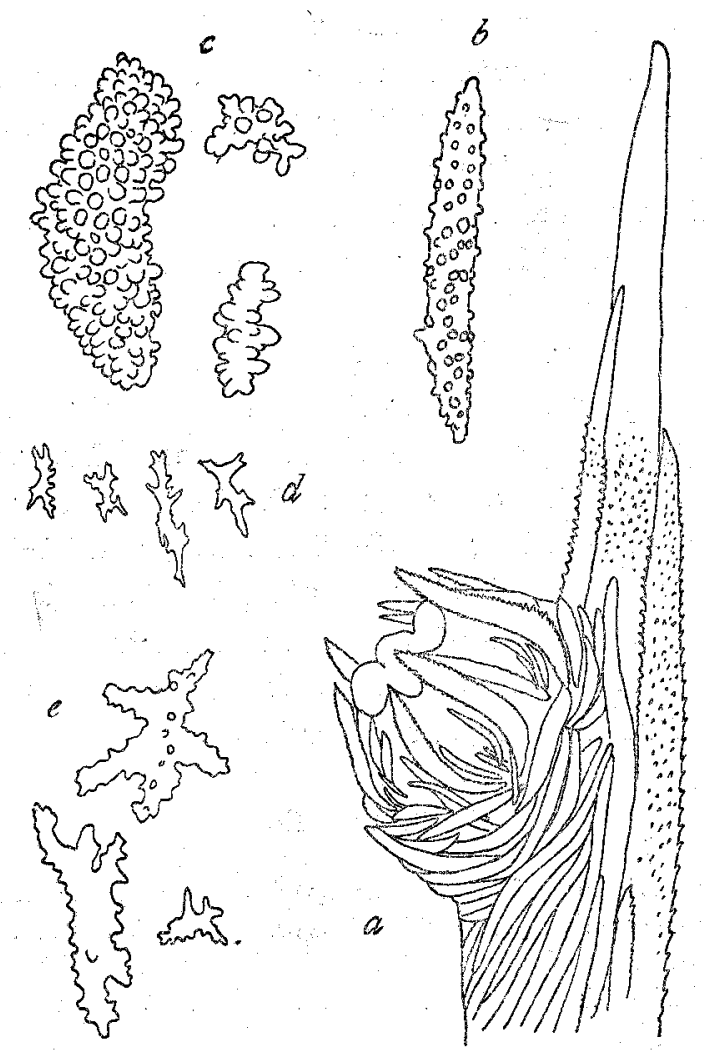

Fig. 29. Dindronephthya gloriosa n. sp. a, Polyp; $b$, spindle from upper cortex; $c$, spicules from lower cortex; $d$, flat antlers from canai walls of branches; $e$, multiradiates from canal-walls of staik.

$\{a \times 35, c \times 55, b, d, e \times 70\}$

points larger than the other, and attains up to $0.7 \mathrm{~mm}$ long and $0.05 \mathrm{~mm}$ wide. Below these about 3 horizontal rows of crown spicules are closely disposed. Between points widely apart there occur 1 to 4 much smaller intermediates basally. Tentacles with pale orange flat rods, up to $0.08 \mathrm{~mm}$ long, closely disposed in 2 rows. S. B. strongly developed, one or two of largest spicules up to $4 \mathrm{~mm}$ long project beyond polyp head for over $1 \mathrm{~mm}$ long, with smooth free tip. Ventral side of polyp stalk densely disposed with large spindles similar to those of S.B., continuing into crown spicules of head. All polyp spicules markedly spinose. Anthocodial formula:

$$
V I=1 \mathrm{P}+3 \mathrm{Cr}+\text { very strong S.B. }+(1-2) \mathrm{M}
$$

Upper cortex densely packed with warty spindles up to $3.5 \mathrm{~mm}$ long and $0.5 \mathrm{~mm}$ wide, mostly lying transversely. In cortex of stalk are more plump, 
smaller spindles densely covered with large rounded warts, up to $1.5 \mathrm{~mm}$ long, leading to much smaller roundish thorny forms. Canal-walls contain antlerlike flat bodies up to $0.1 \mathrm{~mm}$ long which grow larger downwards in form of multiradiate forms up to $0.45 \mathrm{~mm}$ long with scattered low warts.

Coloring. All anthocodial and terminal cortical spicules bright orange, stem and branch cortex pale orange, stalk, whitish, while polyps themselves pale yellow.

Locality. Tanabe Bay. May 1942.

Remarks. There is also a fragment (Plate X, Fig. 23) collected from Kii-ôsima which I would refer to the same species. The general feature of the spiculation and coloration conforms with the preceding description, but the polyps are mostly much larger $(0.6-0.8 \mathrm{~mm}$ long and $1.1-1.3 \mathrm{~mm}$ wide) and paler in coloration, and the projecting tip of S. B. spicules is colored dark red. The spiculation and coloration of this form somewhat resemble those of $D$. punicea (STUDER) of the Glomeratae known from Japan. But the growth form is obviously of the Umbellate type, as described above.

\section{REFERENCES}

GRAY, J. E. 1862. Description of some new species of $S$ pongodes and a new allied genus (Morchellana) in the collection of the British Museum. Proc. Zool. Soc. London, 1862.

1839. Notes on the fleshy Alcyonoid corals. Ann. Mag. Nat. Hist., Ser. 4, vol. 3.

HICKsON, S. J. 1903. The Alcyonaria of the Maldives. Part I. Fauna and Geogr. Maldive \& Laccadive Arch., vol. 2.

- \& I. L. HILES 1900. The Stolonifera and Alcyonacea collected by Dr. WILLEY etc. WILLEY's Zool. Results, Part 4.

HOLM, O. 1895. Beiträge zur Kenntniss der A!cyonidengatcung Spongodes LESs. Zool. Jahrb., Abt. Sys:., Bd. 8.

KüKENTHAL, W. 1896. Alcyonaceen von Ternate. Abh. Senckenb. naturf. Ges. Frankfuri, Bd. 23.

1905. Versuch einer Revision de: Alcyonarien. II. Die Familie der Nephthyiden. 2. Teil. Zool. Jahrb., Abt. Syst., Bd. 21. Abt. 1 .

1906. Japanische Alcyonaceen. Abh. K. Bayer. A'rad. Wiss. II. Sippl.-Bd. 1,

—_ 1911. Alcyonarien von den Aru- und Kei-Inse!n nach den Sammiungen von Dr. H. MERTON. Abh, Senckenb. naturf. Ges. Frankfurt, Bd. 33, Ht. 4.

Macfadyen, L. M. I. 1936, Alcyonaria. Great Barr. Reef Exped. 1928-29 Sci. Rep., vol. 5, no. 2 .

MAY, W. 1900. Beiträge zur Systematik und Chorologie der Alcyonaceen. Jena. Z. Naturw.; Bd. 33.

NUTting, C. C. 1923. Descriptions of the Alcyonaria collected by the U. S. Fisheries Steamer "Albatross" mainly in Japanese waters during 1905. Proc. U. S. Nat. Mus., vol. 43.

PứtTer, A. 1900. Alcyonaceen des Breslauer Museums, Zool. Jahrb., Abt. Syst., Bd. 13.

RIDLEY, S. O. 1882. Contributions to the knowledge of the Alcyoniria, with descriptions of new species from the Indian Ocean and the Bay of Bengal. Ann. Mag. Nat. Hist., Ser. 5. vol. 9 . 
RoXAS, H. A. 1933. Philippine Alcyonaria. II. The famlies Alcyoniidae and Neph:hyidae. Philipp. J. Sci., vol. 50, no. 4.

ShanN, E. W. 1912. Observations on some Alcyonaria from Singapore ete. Proc. Zool. Soc. London, 1912.

SyeRriffs, W. R. 1922. Evolution within the genus Dindronephinya (Spmgodes) etc. Proc. Zool. Soc. London, 1922.

STIMPSON, W. 1856. Descriptions of some of the new marine Invertebrata from the Chinese and Japanese Seas. Proc. Asad. Nat. Sci. Philadelphia, vol. 7.

STUDER, Th. 1888. On some new species of the genus Spongodes LESS. from the Philippine Istands and the Japanese Seas. Ann. Mag. Nat. Hist.; Ser. 6, vol. 1.

THomson, J. A. \& [. M. I. DEAN 1931. The Alcyonacea of the Siboga Expedition. SibogaExpeditie, Mon, 13d. \& W. D. HENDERSON 1906. The marine fauna of Zanzibar and British East Africa etc. Alcyonaria. Proc. Zool. Soc. London, 1906, vol. 1. \& D. MACKINNON 1910. Alcyonarians collected on the Percy Sladen Trust Expedition. Part II. Trans. Linn. Soc. (Zool.) London, vol. 13. \& J. M. MCQUEEN 1908. Reporis on the marine biology of the Sundanese Red Sea. VIII. The Alcyonarians. J. Linn. Soc. (Zool.) London, vol. 31. \& J. J. SIMPSON 1909. An account of the Alcyonarians collected by the Royal Indian Marine Survey Ship "Investigator" in the Indian Ocean. Part IL. The Alcyonarians of the littoral area.

VERRILL, A. E. 1864. List of the polyps and corals sent by the Museum of Comparative Zoölogy to other institutions in exchange, with annotations. Bull. Mus. Comp. Zoöl., vol. 1. 1865. Synopsis of corals and polyps of the North Pácific Exploring Expedition etc.

Part II. Proc. Essex Inst., vol. 4, no. 10.

WRIGHT, E. P. \& Th. STUDER 1889. Alcyonaria. Challenger Report, vol. 31. 


\section{EXPLANATION OF PLATE IX}

Fig. 1. Dendronephthya nipponica n. sp. (Holotype)

$\times 1 / 2$.

2. D. nipponica n. sp., from below. (Holotype)

$\times 1 / 2$.

3. D. gigantea (VERRILI).

$\times 1 / 2$.

4. D. gigantea (VERRLL), young compact colony.

$\times 1 / 2$.

5. D. tuberculata n. sp. (Holotype)

$\times 1 / 2$.

6. D. aculéata KüKeNTHAL.

$\times 4 / 5$.

7. D. aurea n. sp. (Holotype)

$\times 1 / 3$.

8. D. japonica KǘKeNTHAL.

$\times 1 / 2$.

9. D. palmata n. sp. (Holotype)

$\times 1 / 2$.

10. D. furcata n. sp. (Holotype)

$\times 1 / 2$ 。

\section{EXPLANATION OF PLATE X}

Fig. 11. Dendronephthya palaoensis n. sp. (Holotype)

$\times 1 / 2$.

12. D. golgotha n. sp. (Holotype)

$\times 3 / 5$.

13. D. cervicornis (WRIGHT \& STUDER).

$\times 3 / 5$.

14. D. spinulosa (GRAY).

$\times 1 / 2$.

15. D. dromidicola n. sp. (Holotype)

$\times 1 / 2$.

16. D. pellucida n. sp. (Holotype)

$\times 1 / 5$.

17. D. habereri KüKENTHAL.

$\times 1 / 2$.

18. D. disciformis KǘKENTHAL.

$\times 4 / 5$.

19. D. castanea n. sp. (Holotype)

$\times 4 / 5$.

20. D. acaulis KüXENTHAL. ( $\mathrm{Sp} . \mathrm{C})$

$\times 4 / 5$.

21. D. acaulis KürenthAL. (Sp. B)

$\times 4 / 5$.

22. D. densa KÜKENTHAL, fragment.

$\times 4 / 5$.

23. D. gloriosa n. sp., fragment from Kii-ôsima.

$\times 4 / 5$.

24. D. gloriosa n. sp. (Holotype)

$\times 3 / 4$.

\section{EXPLANATTON OF PLATE XI}

Fig. 25. Dendronephinya decussatospinosa n. sp. (Holotype) $\quad \times 1 / 2$.

26. D. alba n. sp. (Holotype) $\times 1 / 2$.

27. D. filigrana KüKENTHAL. $\times 1 / 2$.

28. D. dofleini KükenthaI, fragment. $\quad \times 2 / 3$.

29. D. divaricaia (G $\mathrm{RAY})$. $\times 2 / 3$.

30. D. pulchella n. sp. (Holotype) $\times 2 / 3$.

31. D. pectinata (HOLM), young colony. $\quad \times 2 / 3$.

32. D. pectinata (Holm) from Tanabe Bay. $\quad \times 1 / 2$.

33. D. pectinata (HolM), upper part of large colony. $\times 1 / 2$.

34. D. longicaulis KüKENTHAL, upper part of large colony. $\quad \times 1 / 2$. 

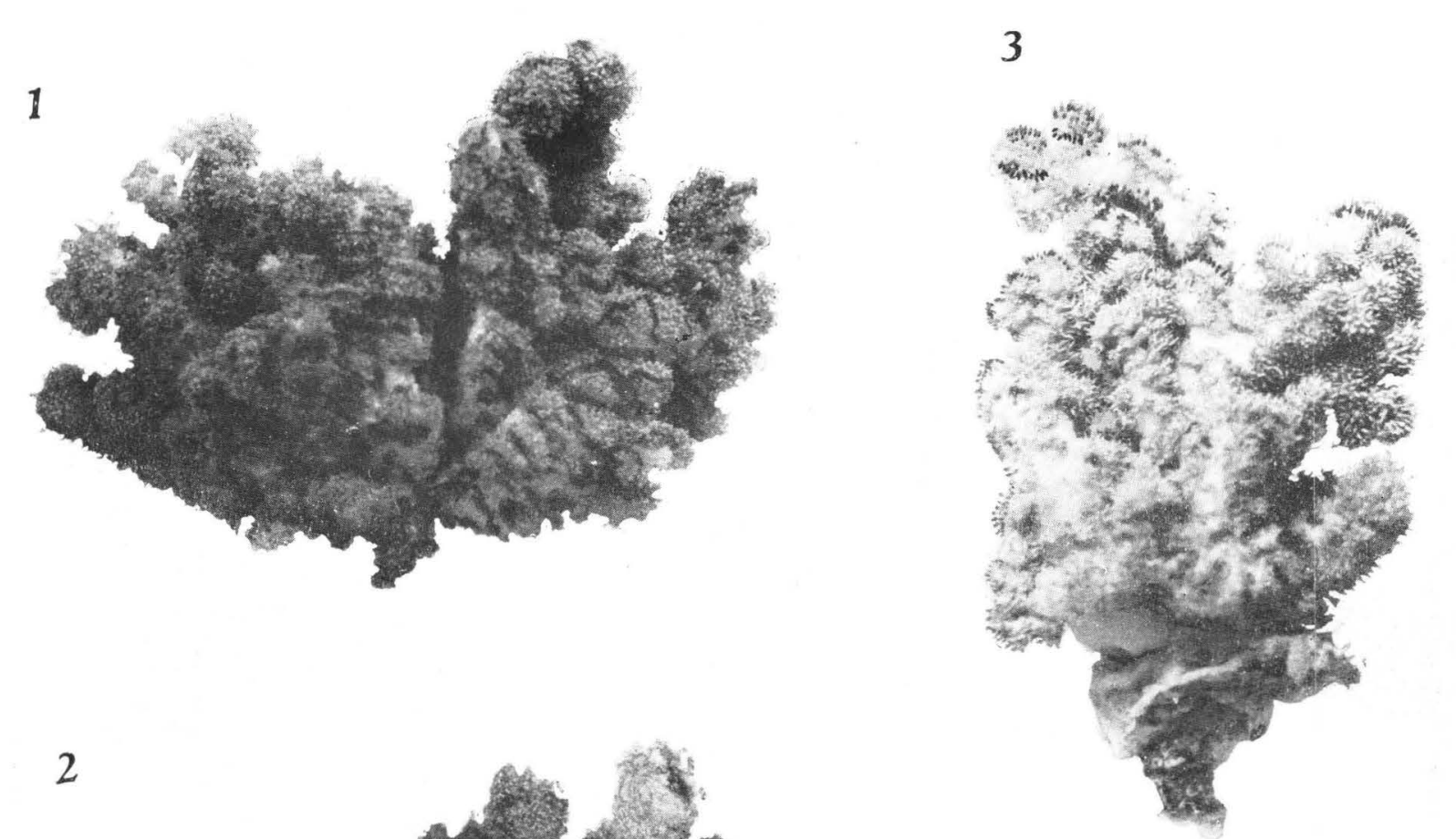

5
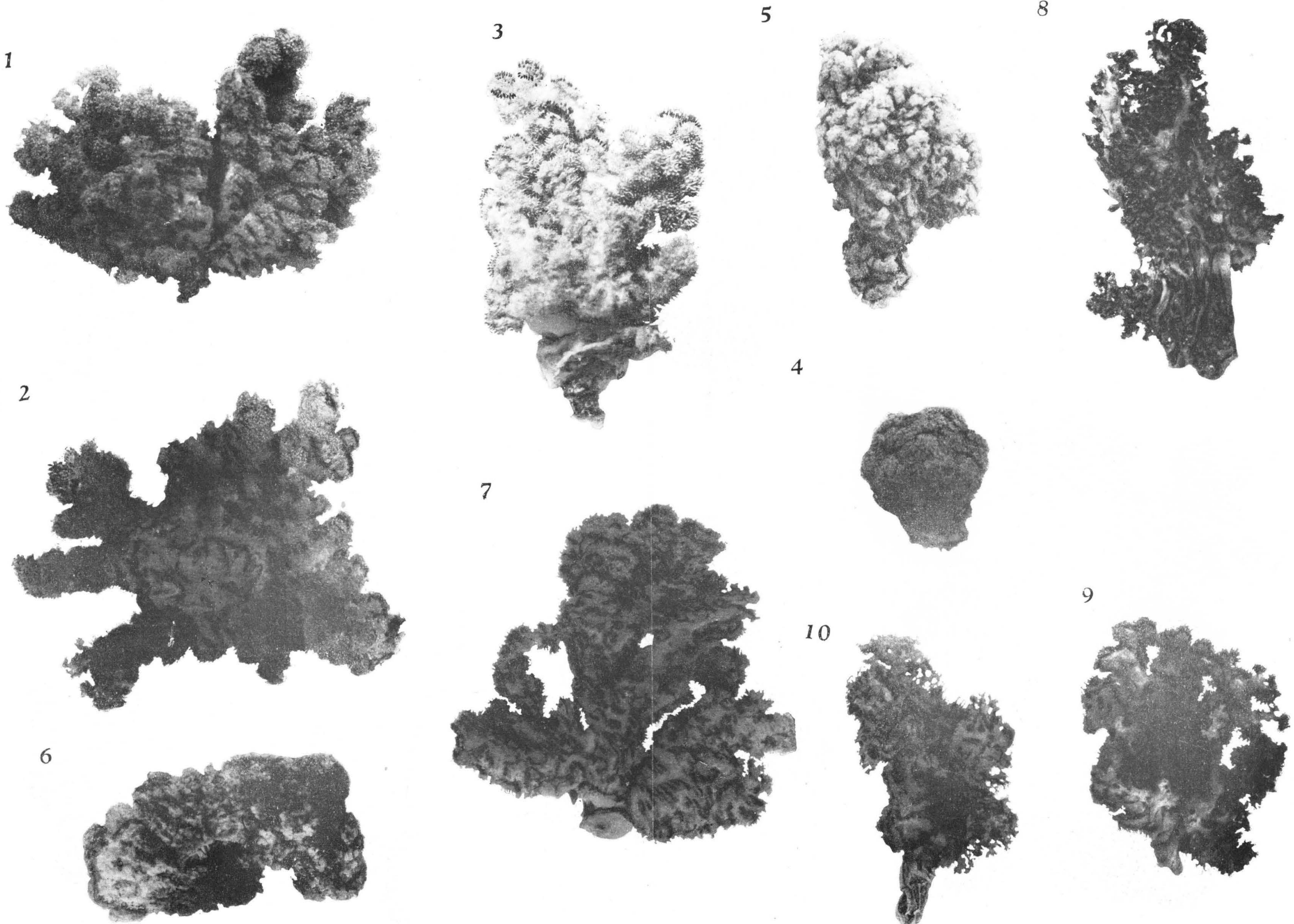

6
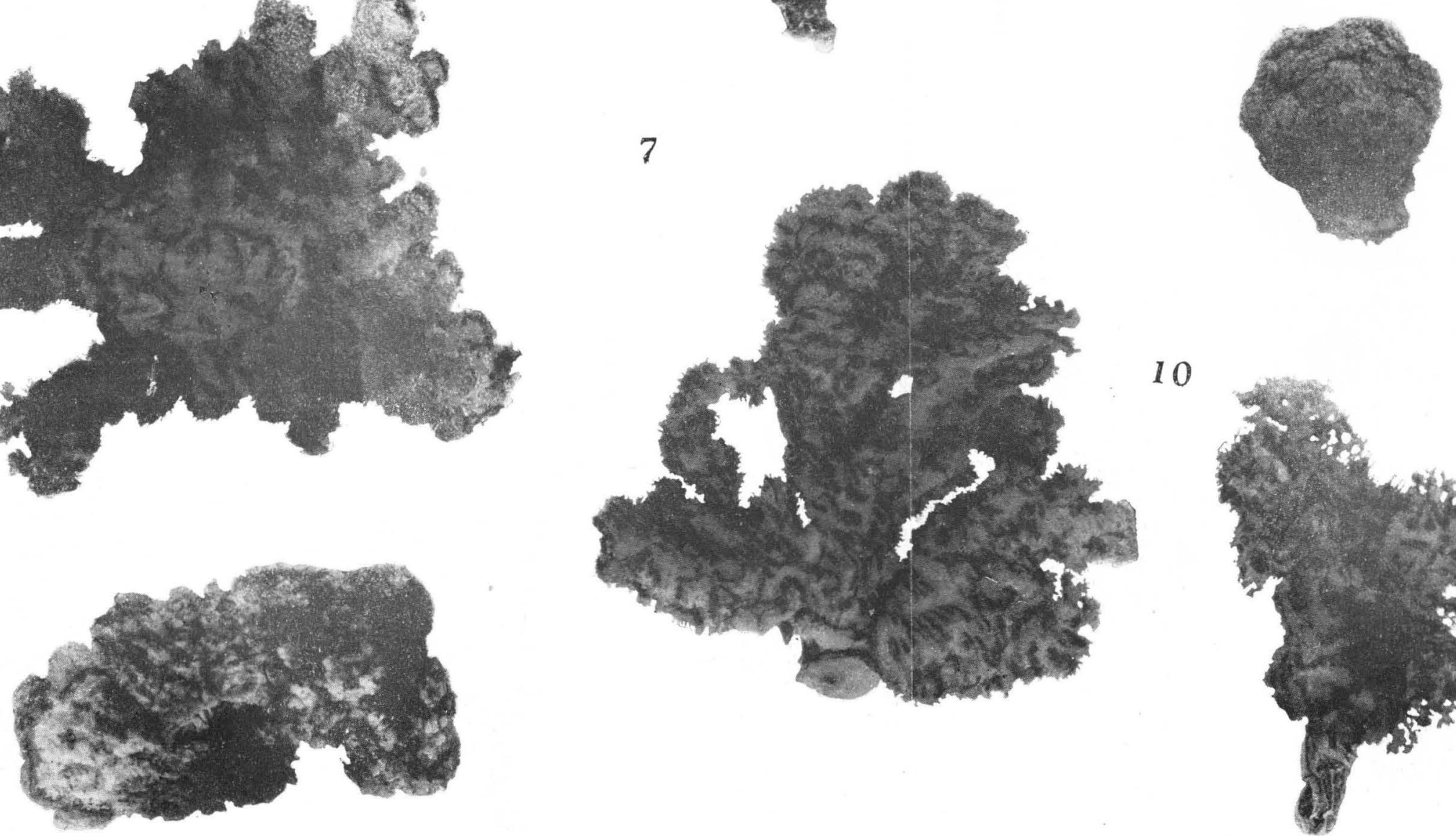

10

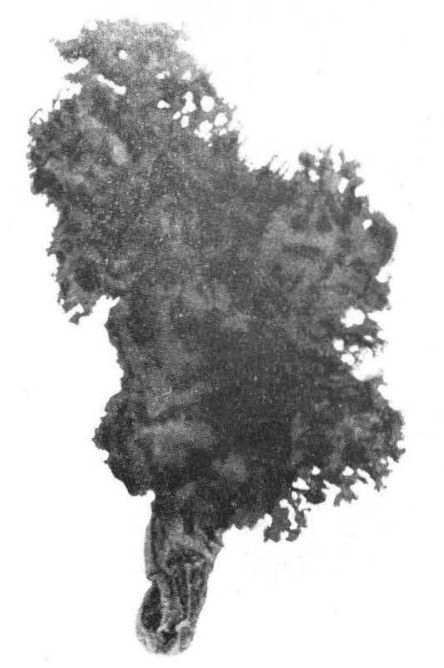

9

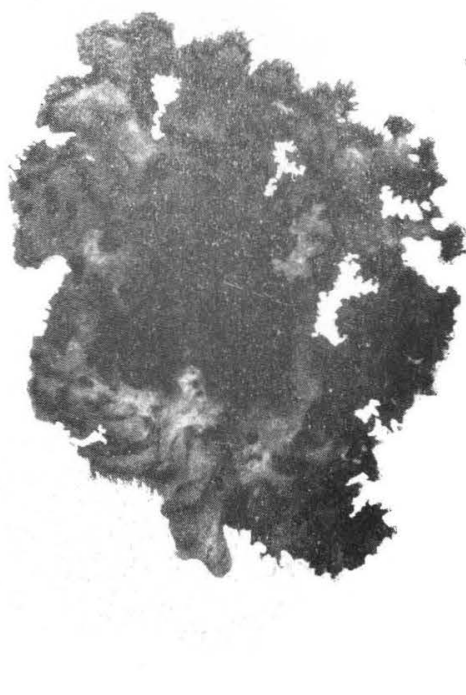

H. Utinomi: Dendronephthya of Japan. (I) 
11

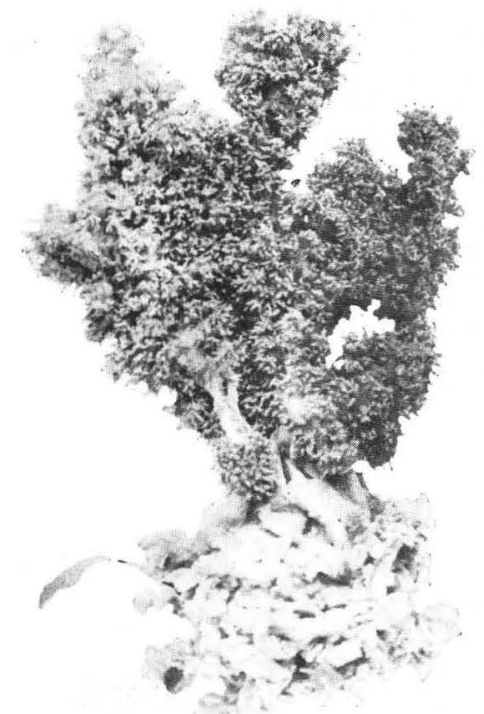

14

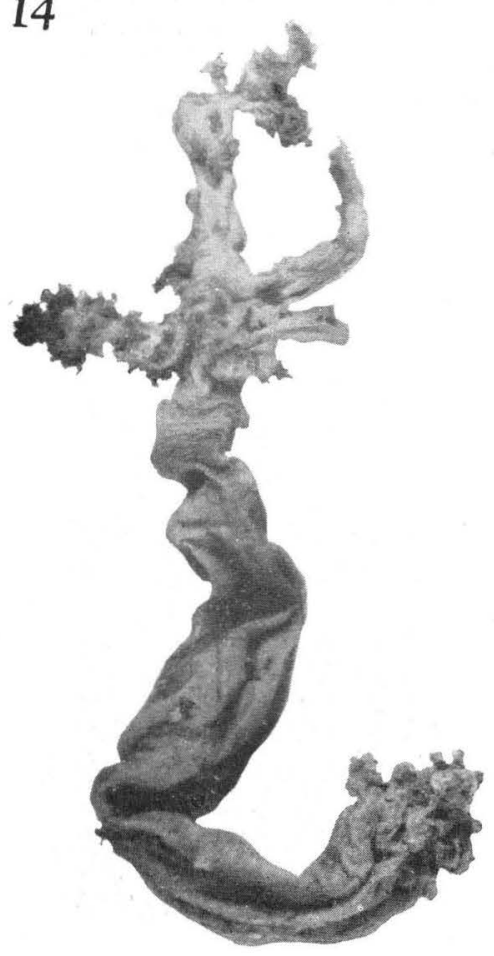

12

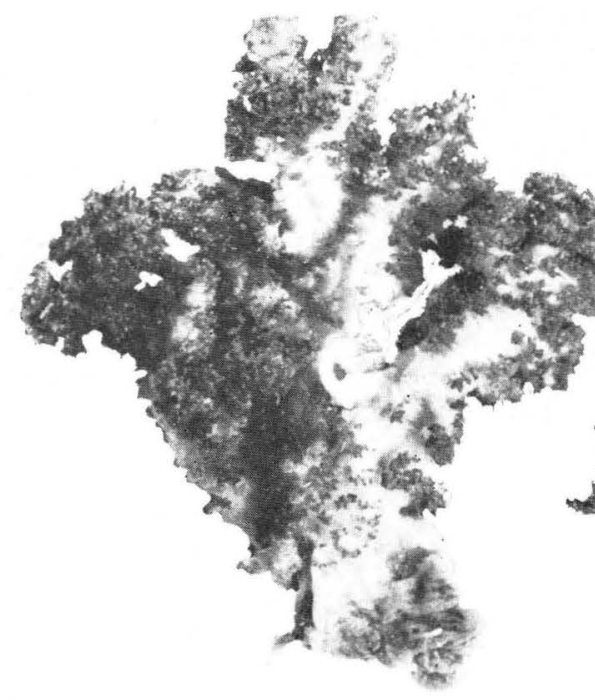

13

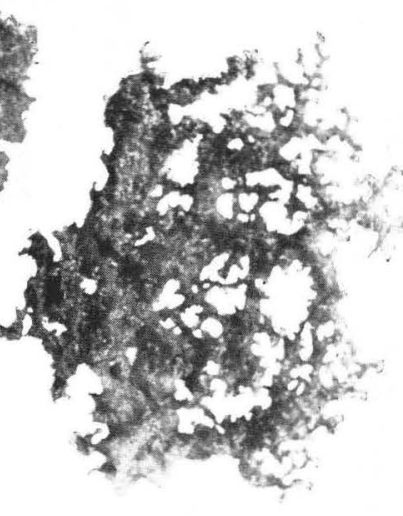

17

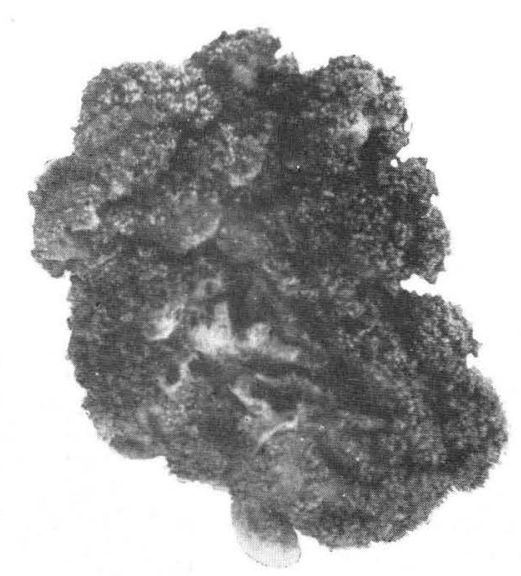

18
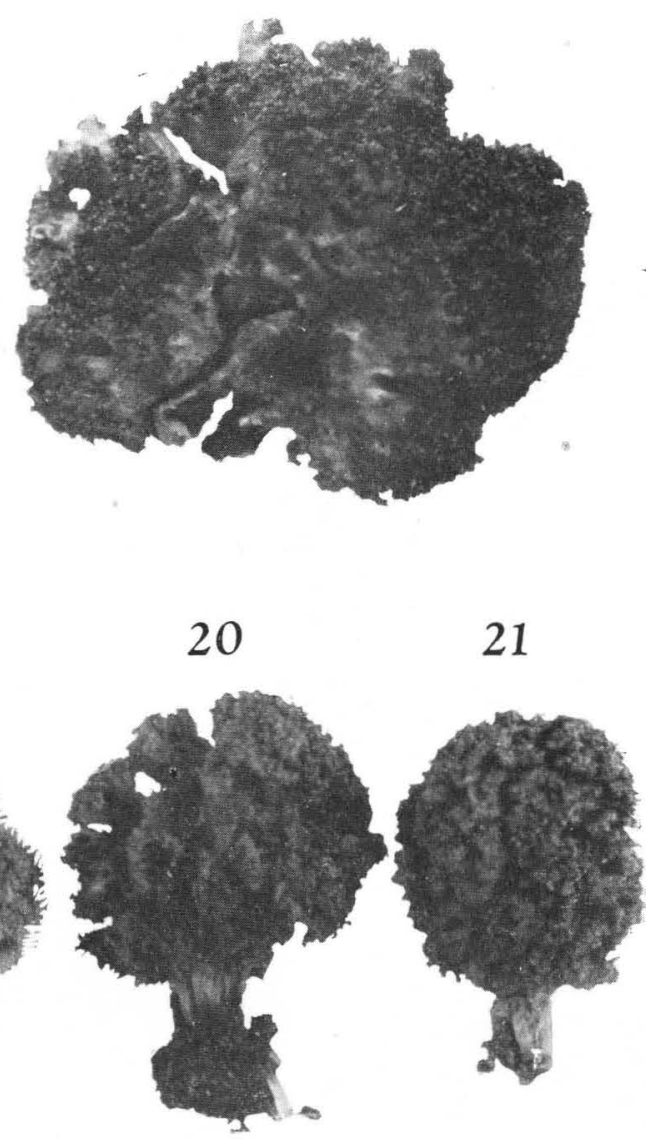

22

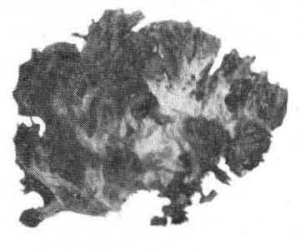

23

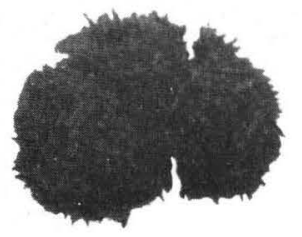

24

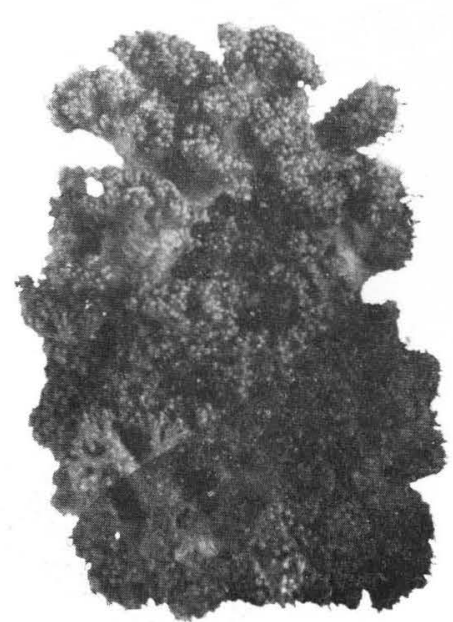

H. Utinomi : Dendronephthya of Japan. (I) 


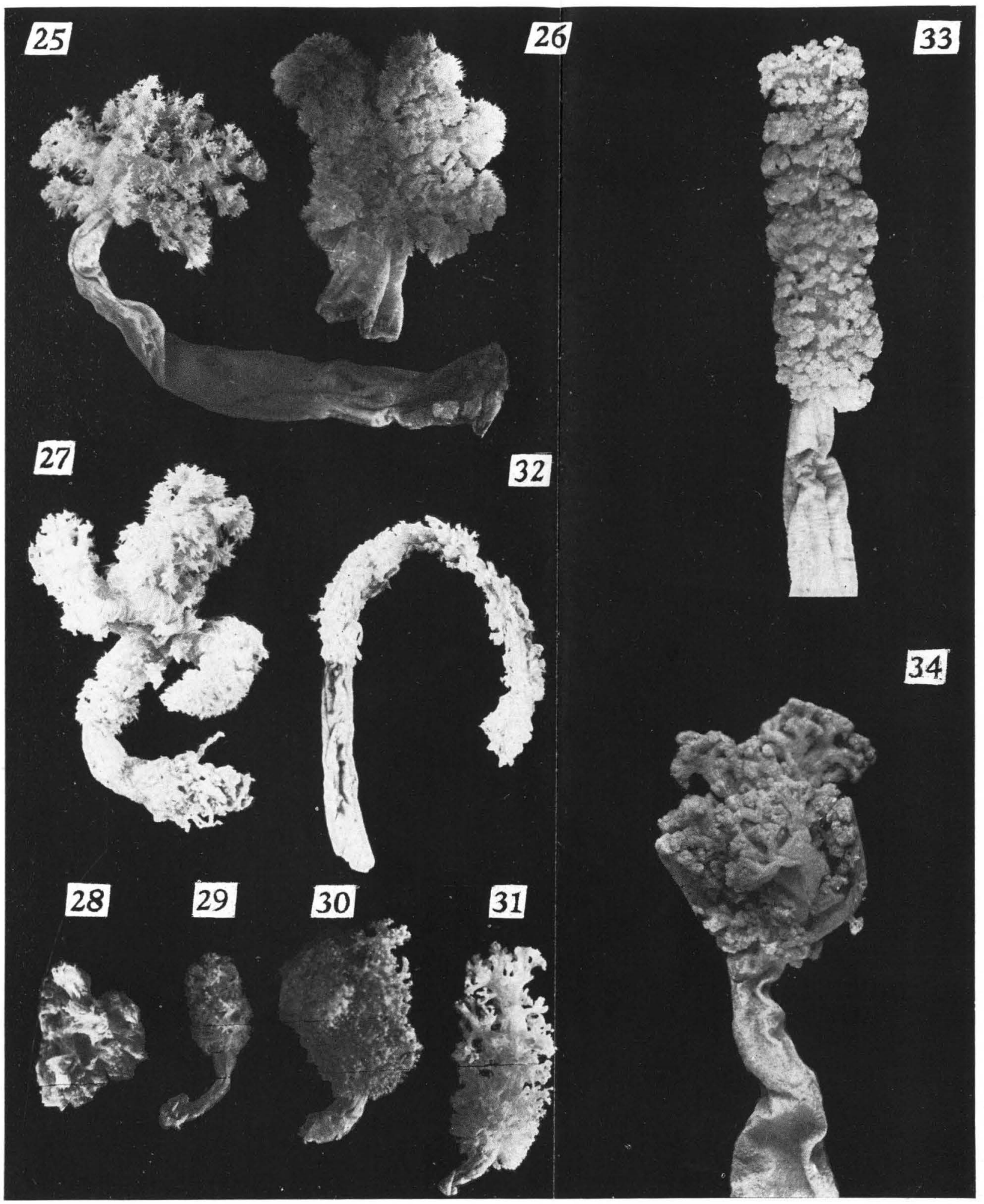

H. Utinomi : DendRonephthya of JAPAN. (I) 